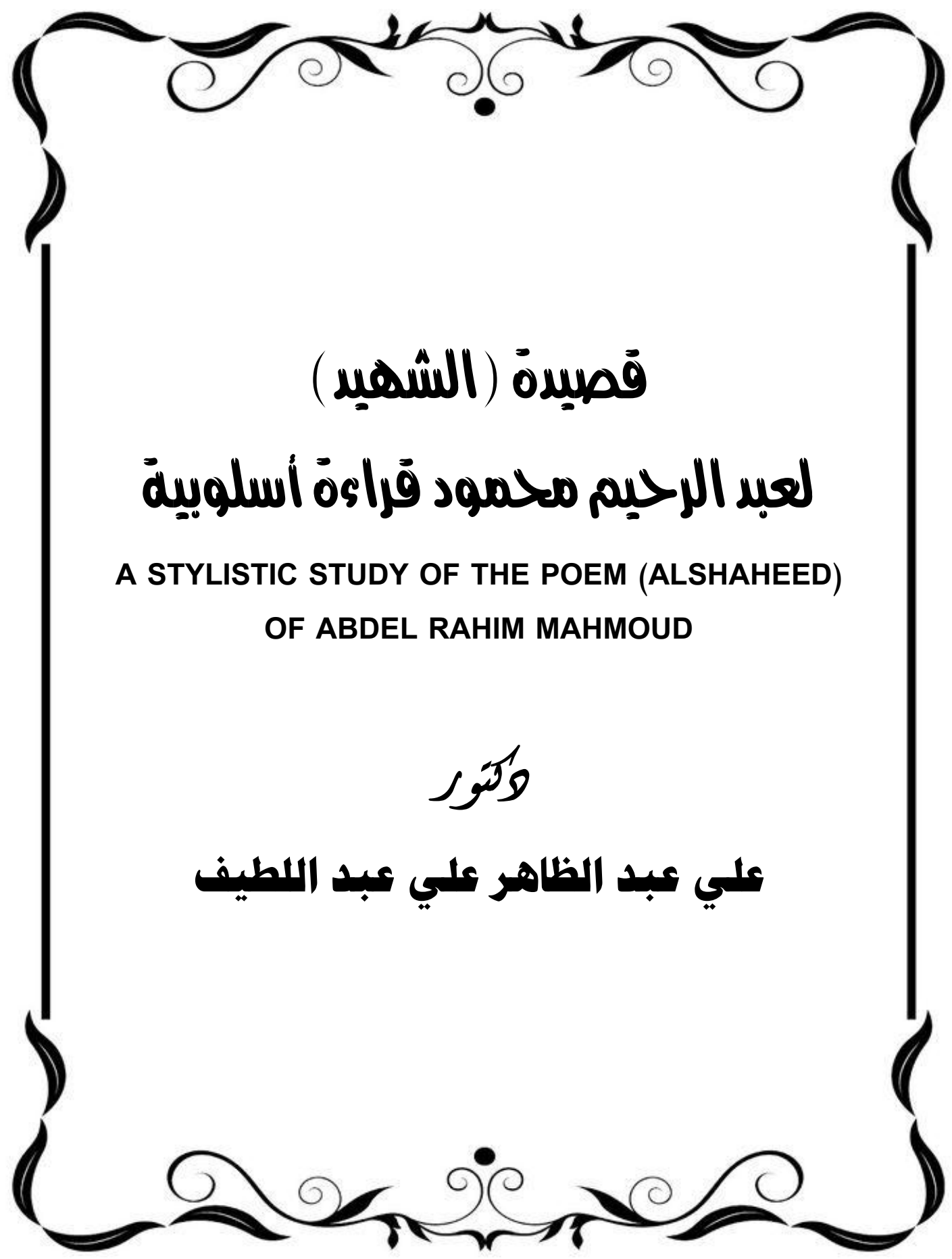



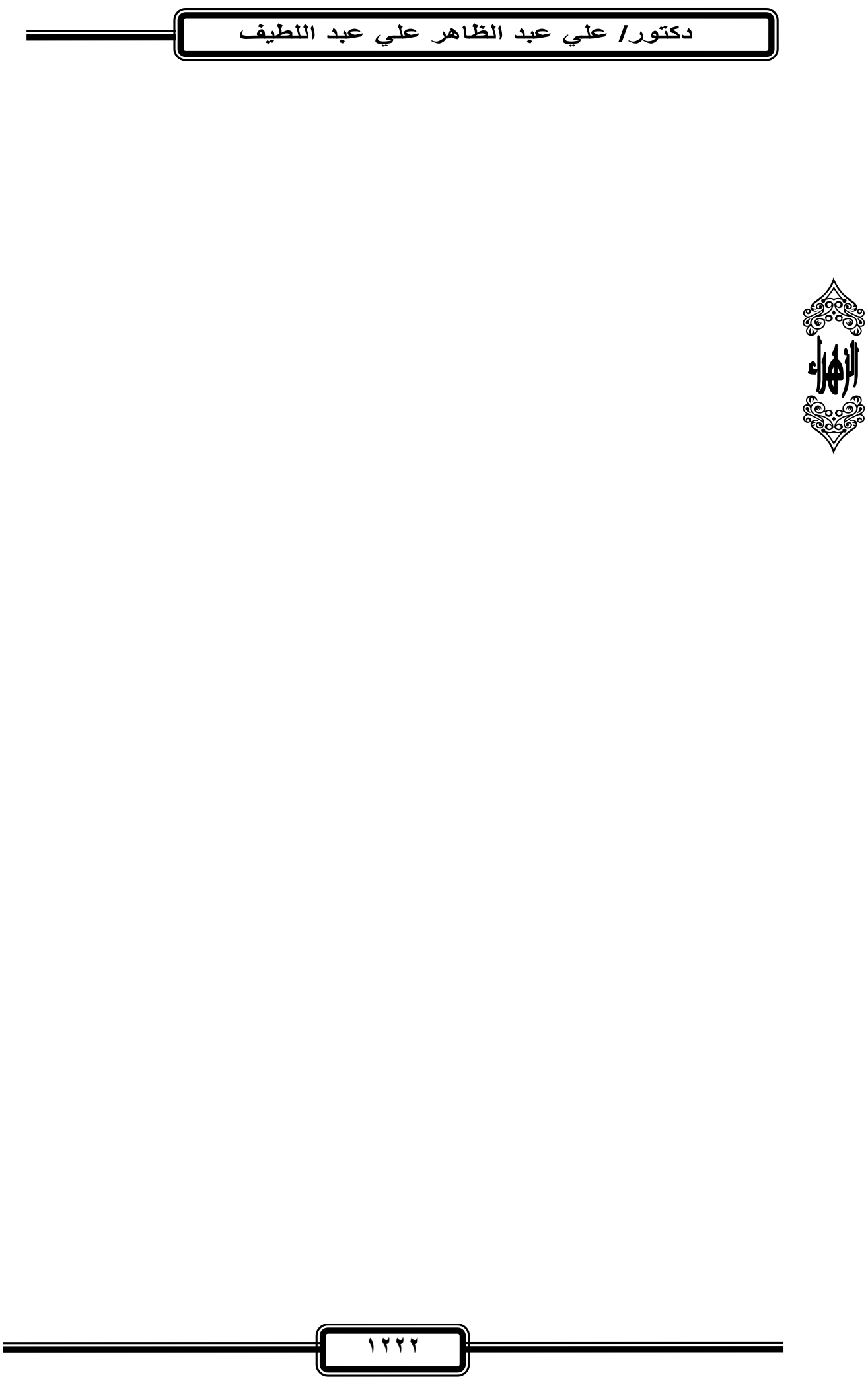
قصيدة (الثهيد) لعبد الرحيم محمود قراعة أسلوبية
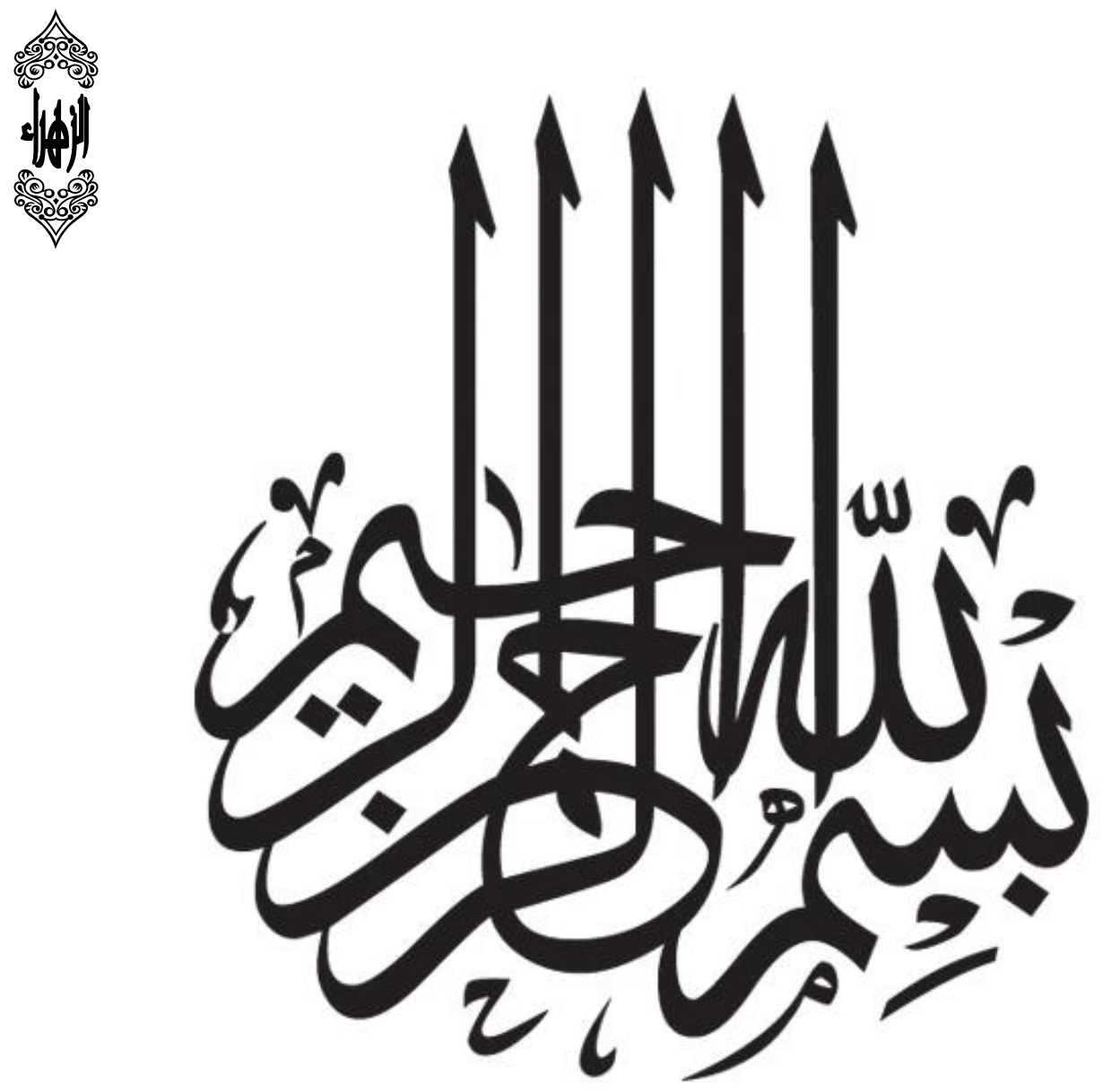

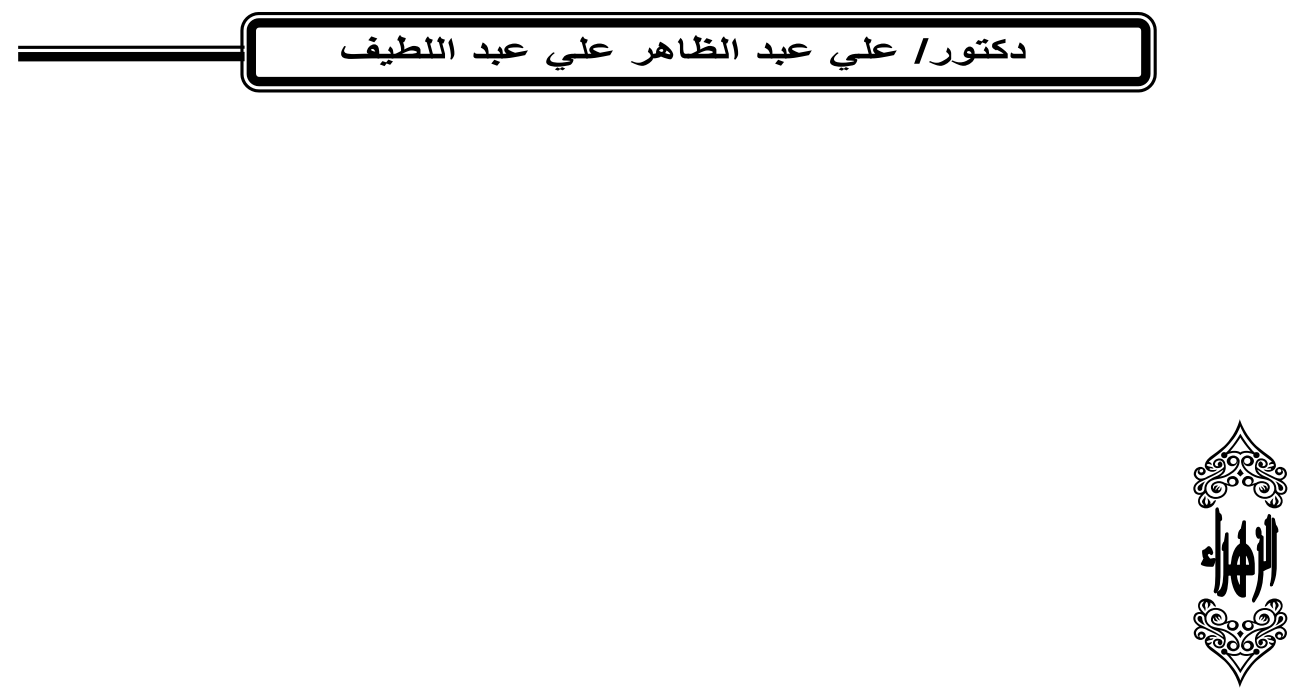


\section{|ll| |ll|}

تلقي هذه الدراسة الضوء على قصدة (الثهيد) للثاعر الفلسطيني عبد الرحيم محمود، تلك القصيدة التي كتبها قبل وفاته بنحو تسع سنوات، وكأنه يرثي بها نفسه، وقد هدفت دراستنا إلى الغوص في أعماق القصيدة من خلال دراسة أسلوبية تكثف عن مكنوناتها حيث تم تحليلها أسلوييًا

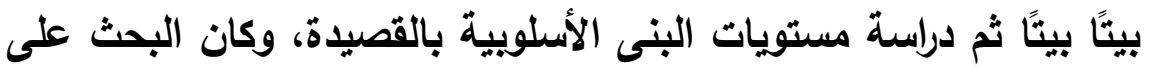
ثُلاثة مستويات شكّلت بمجملها حضوراً فاعلاً وسيادياً في القصيدة موضوع الدراسة، وهي المستوى الصوتي الذي تناول الجاتب الوظيفي الفونولوجي وتطرق إلى الإيقاع الخارجي المتمثل في الوزن والقافية مبينًا

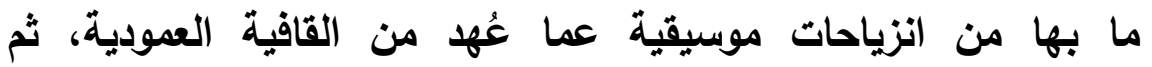
الموسيقى الداخلية ومؤئراتها الإيقاعية، ويليه الجانب التركيبي الذي غُنى لأنى

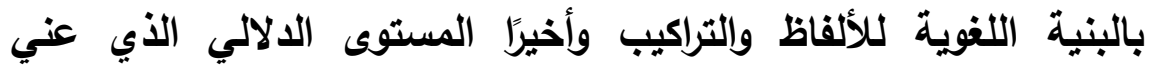
بالجانب التصويري والأساليب الإنثائية، كان هذا للكثف عما تزخر به الهابه

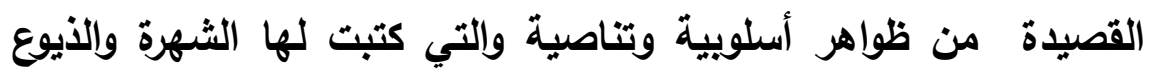
وجعلت لها مكانة مرموقة في شعر المقاومة والثعر الوطني والحديث

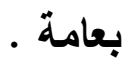


دكتور/ علي عبد الظاهر علي عبد اللطيف

\section{ABSTRACT}

This study sheds light on the poem (Alshaheed) of the Palestinian poet Abdel Rahim Mahmoud, the poem that he wrote about nine years before his death, as if he were inspired by himself. Our study aimed to dive into the depths of the poem through a stylistic study, And the study of the levels of stylistic structures in the poem. The research came at three levels, which constituted an active and sovereign presence in the poem. The subject of the study is the phonological level, which dealt with the functional aspect of phonology. A period of vertical rhyme, then internal music and its rhythmic effects, followed by the structural aspect, which is concerned with the linguistic structure of the words and structures, and finally the semantic level to me on the photographic side and the structural methods. This was to reveal the poem's richness of stylistic phenomena, In the poetry of the denominator and the national poetry and the modern in general. 
هذه قصيدة (الشهيد) للشاعر الثهيد عبد الرحيم محمود، ابن الثيخ محمود عبد الحليم عبد الله، ولد في عنبتا التي تقع بين طولكرم ونابلس

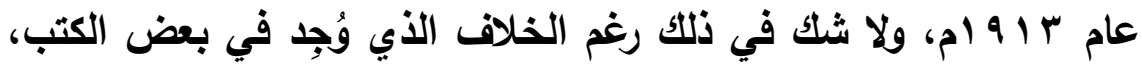

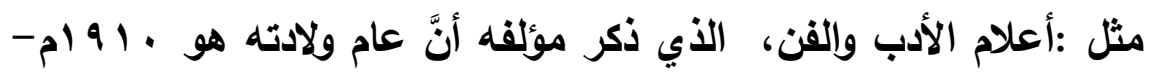

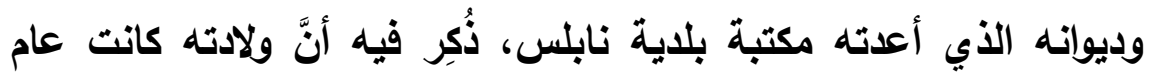

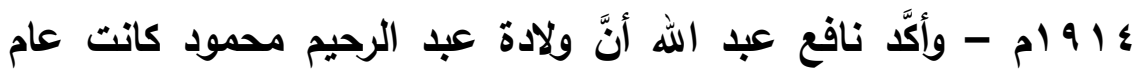
ب ا 19 1، وكان دليله من خلال شهادته المدرسية وديوانه .

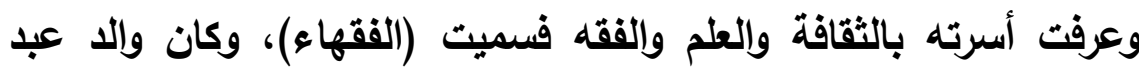

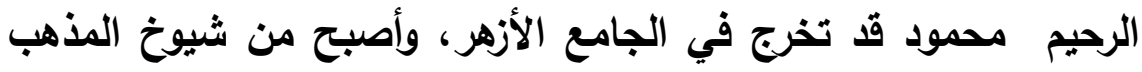

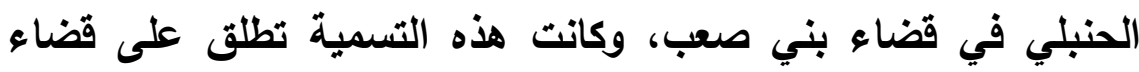
طولكرم في ذلك العصر . وتزوَّج الثيخ محمود والد عبد الرحيم ثُلاث نساء، كانت آخرهن والدة عبد

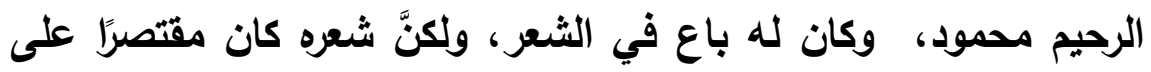

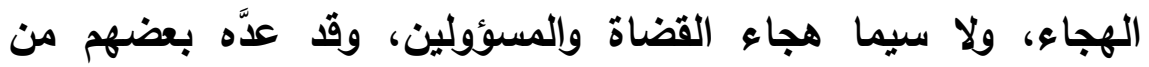

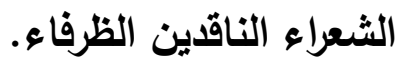
عاش عبد الرحيم محمود طفولته الأولى في كنف واللايه، فكان من الطبيعي أن يغرس الوالد الثيخ في نفس ولده حب العلم والدين، ولكنَّ

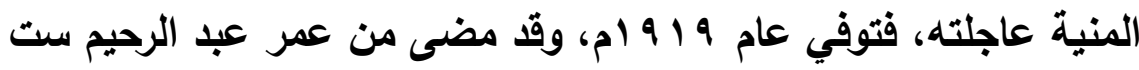
سنوات فقط، فعرف عبد الرحيم معنى اليتم في مستهل حياته.

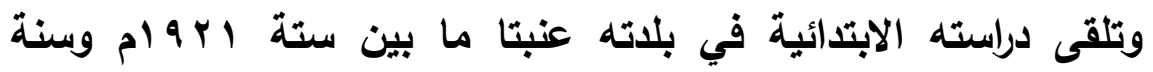
ه 9 ام، وواصل دراسته الثانوية المتوسطة (الاستعدادية) في مدينة الائه 
طولكرم (في المدرسة الفاضلية حاليا)، إذ مكث فيها أربع سنوات أخرى،

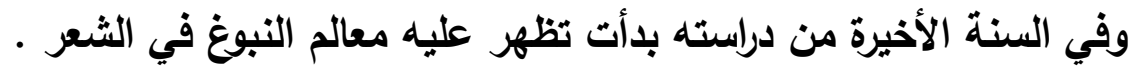

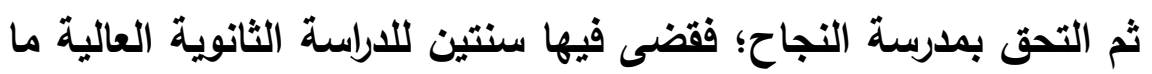

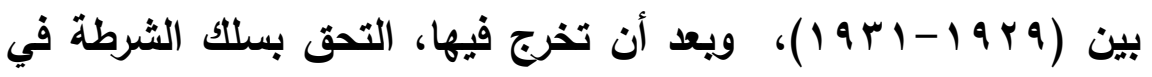

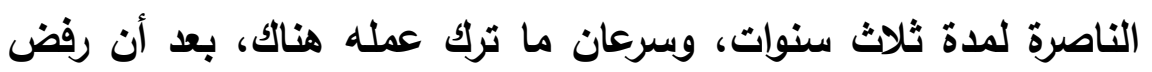

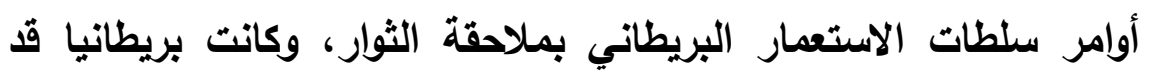

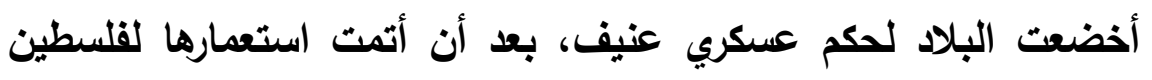

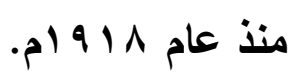

ترك عبد الرحيم محمود الناصرة، وتوجه للعمل في مدرسة النجاح،

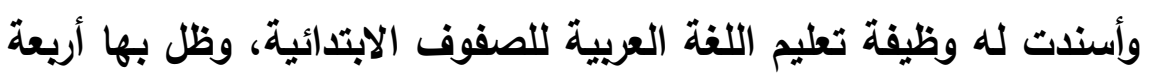

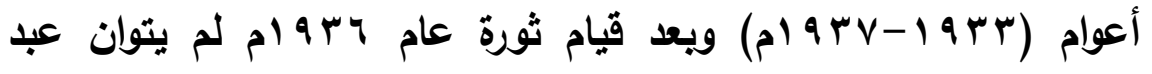

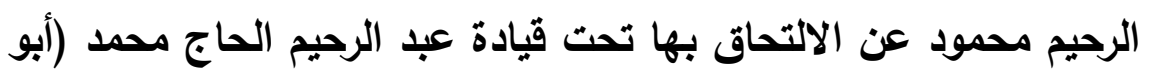

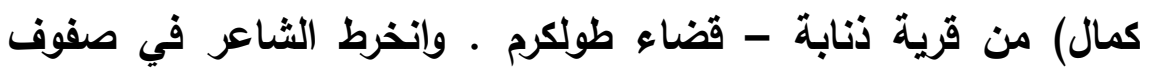

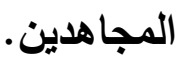
ويعد انتهاء الثورة توجَه عبد الرحيم محمود إلى العرلق، لاسيما انه كان

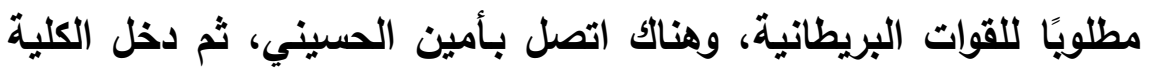
العكرية في بغداد برتبة ملازم ثان، ويرز في مدرسة العثّار الابتائية

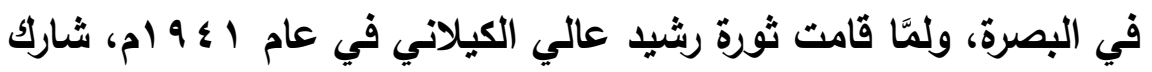

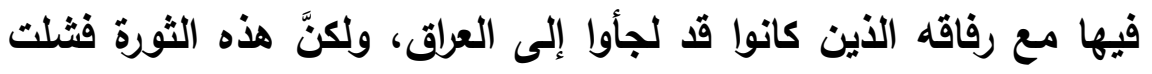

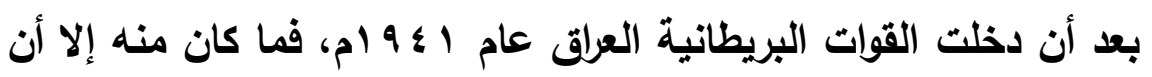

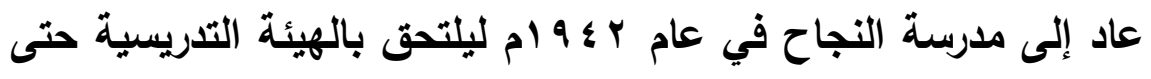

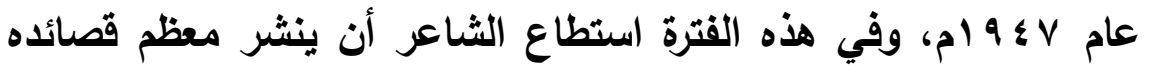

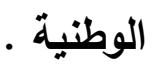


ويعد قرار التقسيم التحق بجيش الإنقاذ بقيادة فوزي القاوقجي، وكان عبد الرحيم محمود قد سافر إلى دمثق في كانون الثاني من عام 1 ـ 9 ام، حيث تدرَّب في قطنة في محافظة دمثق، ولكنه سرعان ما رجع إلى في إلى

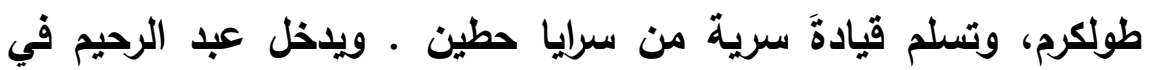

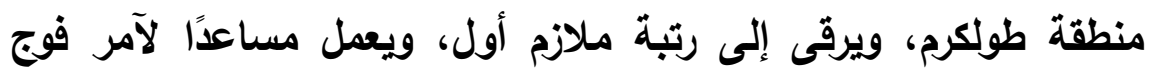

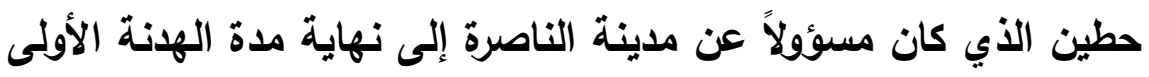

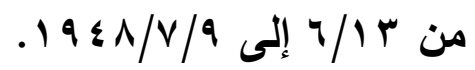
وتثتد المعارك بين الصهاينة والمجاهدين الفلسطينيين، إذْ حاول الصهاينة احتلال (الثجرة) بمحاولات مستميتة من جانبهم، وكان عبد

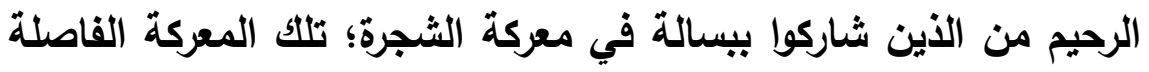

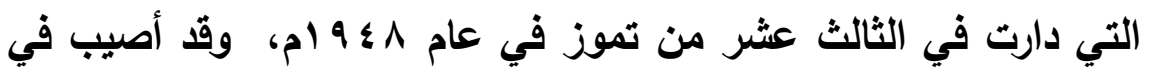

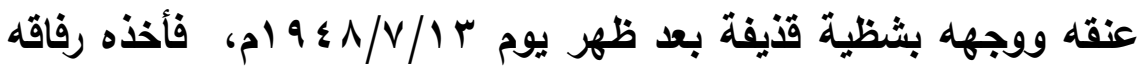
في سيارة عسكرية إلى مستثفى الميدان في الناصرة، ثم سقطت السيارة

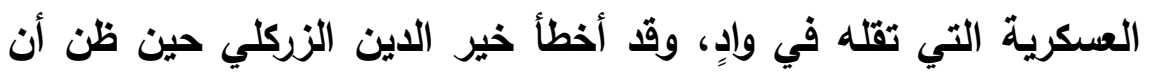
عبد الرحيم محمود فاضت روحه في هذا الحادث، لكنَّ الحقيقة أن رفاقه

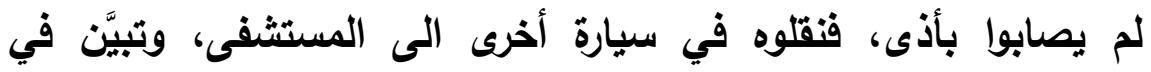

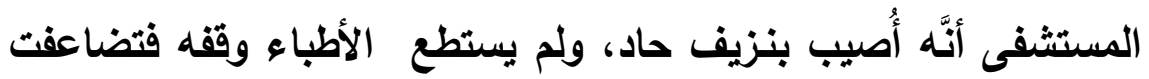

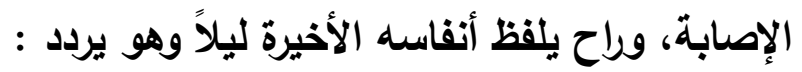

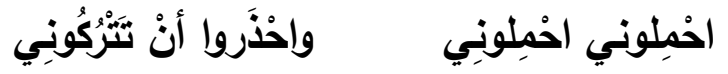

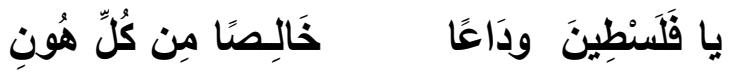

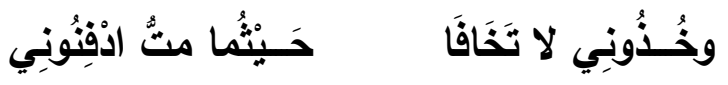

وقد تمَّ دفنه في مدينة الناصرة، حيث كانت رغبته ووصيته ـ (1) 
صدر ديوان عبد الرحيم محمود في خمس طبعات، وهي على التوالي:

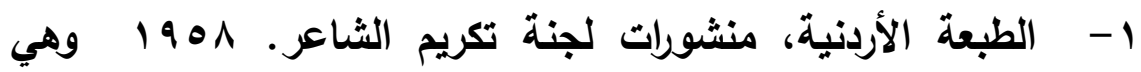
- (بيتاًاً r - طبعة كامل السوافيري، منشورات اتحاد كتاب فلسطين، بيروت. .

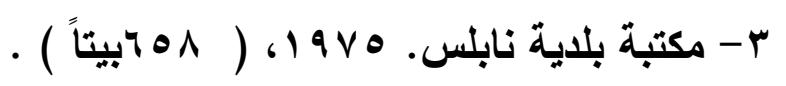

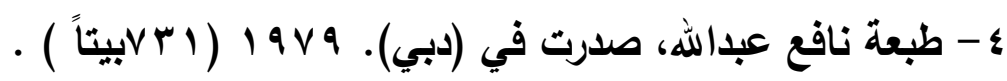
ه- طبعة حنا أبو حنا، منشورات مركز التراث، الطيبة، فلسطين - 1 ـ .

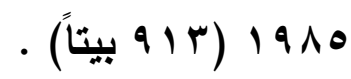

الأعمال الكاملة لعبد الرحيم محمود: الايوان، والمقالات النقدية: صدرت الأعمال الكاملة للشاعر عبد الرحيم محمود في ثلاث طبعات: ا. الطبعة الأولى- جمع وتحقيق: عز الدين المناصرة، دار الجليل،

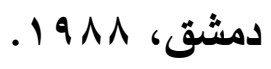
r. الطبعة الثانية- جمع وتحقيق: عز الدين المناصرة، دار الكرمل،

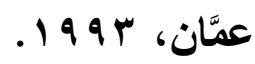
r. الطبعة الثالثة- جمع وتحقيق: عز الدين المناصرة، دار جرير،

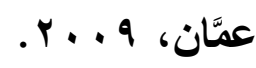
الأسلوبية وردث لفظة (أسلوب) في كلام العرب منذ القدم، فقد جاء في لسان العرب لابن منظور: - n "... ، ويقال للسطر من النخيل: أسلوب، وكلّ طريق ممتد فهو أسلوب، والأسلوب: الطريق، والوجه، والمذهب(Y)"، بيد أنّ هذه المعاني قد اتسعت هن

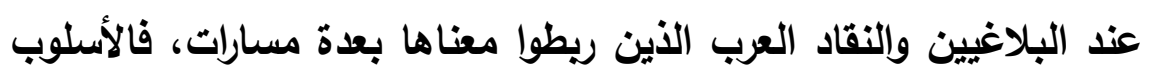


عند بعضهم يدّل علي طريقة العرب في أداء المعنى، مثلما نجد ذلك عند

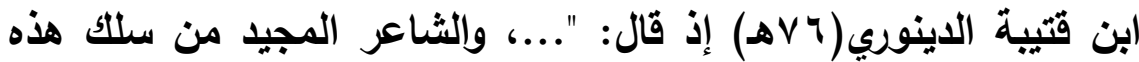

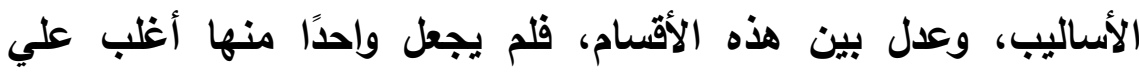
الثعر، ولم يطل فيملّ السامعين، ولم يقطع ويالنفوس ظمأ اللي

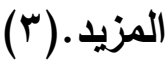

وقد تبلورت فكرة الأسلوب عند القدامي في تعريف ابن خلدون (^ • ^هـ)،

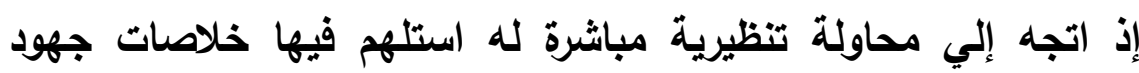
سابقيه من البلاغيين والنقاد العرب حيث قال: "ولنذكر هنا سلوك الأسلوب عند أهل الصناعة، وما يريدون بها في إطلاقهم فاعلم انها عبارة عندهم

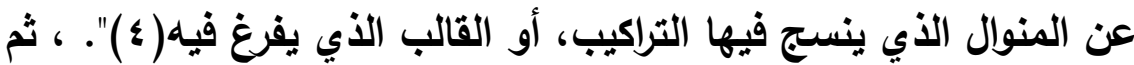
حدَّد مفهوم الأسلوب في الإبداع الأدبي فذكر أنه يرجع إلي "صورة ذهنية البهاب

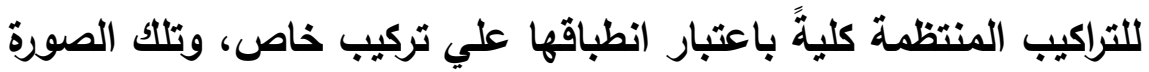
ينتزعها الذهن من أعيان التراكيب وأثخاصها، ويصيرها في الخيال كالقالب أو المنوال ثم ينتقي التراكيب الصحيحة عند العرب باعتبار

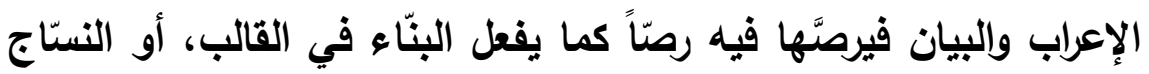

$$
\text { في المنوال." (•) }
$$

وقد استوعب المحثثون العرب المعاني التي طرقها القدماء في تعريفهم الأسلوب، لذلك جاءت هذه التعريفات مقارية لتلك المعاني في مضمونها

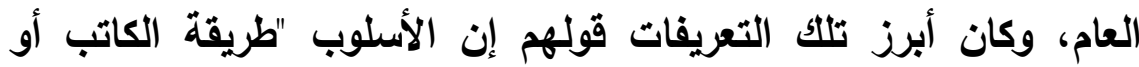

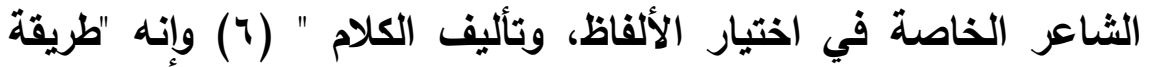
الكتابة، أو طريقة الإنشاء، أو طريقة اختيار الألفاظ وتأليفها للتعبير بها

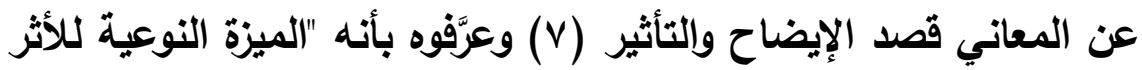
الأدبي (^) وقالوا إن الأسلوب هو "قوام الكثف لنمط التفكير عند 
صاحبه"(9) وقيل هو "الصورة اللفظية التي يعبّر بها عن المعني، أو نظم الكلام وتأليفه لأداء الأفكار، وعرض الخيال، أو هو العبارات اللفظية المنسقة لأداء المعاني ".( • () ويتعدد التعريفات تعددت طرائق صياغتها، بيد إنها تكاد تلتقي في معني جوهري يراد به ان الأسلوب هو طريقة اختيار الكاتب لأدواته الكتابية بالشكل الذي يميزه عن غيره، ويحكم له بالتفرد في صياغة أفكاره والتعبير عنها. ومن هنا يتضح لنا الفرق بين الأسلوب والأسلوبية (علم الأسلوب) وهي كما يلي (11): - الأسلوب وصف للكلام، أمَّا الأسلويية فإنها علم له أسس وقواعد

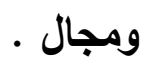
- الأسلوب إنزال للقيمة التأثرية منزلة خاصة في السياق، أما الأسلويية فهي الكثف عن هذه القيمة التأثرية من ناحية جمالية ونفسية وعاطفية. - الأسلوب هو التعبيز اللساني والأسلويية دراسة التعبير اللساني . أما الأسلويية فهي تتجاوز النص المحلل المطلومة أساليبه إلي نقد تثلك الأساليب بناء علي منهج من مناهج النقد المعروفة (Y I)، ولكن الذي الذي يظهر أن الفرق بينهما ضئيل جدا وأنهما يلتقيان في كثير من الجواتب . أما عن الأسلوب في الدراسات الغربية، فيبدو أن الغربيين قد أخذوا كلمة (أسلوب) (Style) من الكلمة اللاتينية (Stylus) ، وتعني قضيبًا من الحديد كان القدماء يكتبون به علي ألواح الثمع (ب I)، ويعني عندهم اصطلاحًا "استخدام الكاتب لأدوات تعبيرية من أجل غايات أدبية، ويتميز في النتيجة من القواعد التي تحدد معني الأثكال وصوابها" . يرتكز حقل الأسلوبية علي ثنائية تكاملية هي من مواضعات التفكير الألسني، وقد أحكم سوسير استغلالها علمياً ، وتتمثل في تفكيك مفهوم 


\section{قصيدة (الثهيا) لعب الرحيم محمود قراعة أسلوبية}

الظاهزة الألسنية إلي واقعين، أو لنقل إلي ظاهرتين وجوديتين، ظاهرة اللفة، وظاهرة العبارة، وقد اعتمد كل الألسنيين بعد سوسير هذا لها الثنائي فحاولوا تركيزه وتدقيقه بمصطلحات تتلون بسمات اتجاهاتهم الألسنية

ويحسب هذه الفكرة فقد أفادت الأسلوبية من علم اللغة الحديث فكرتين

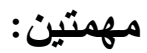

الأولي :التمييز بين اللغة والقول التي قال بها العالم دي سوسير، إذ ميَّز بينهما تمييزًا دقيقًا، فاللغة عنده نظام متعارف عليه من الرموز التي

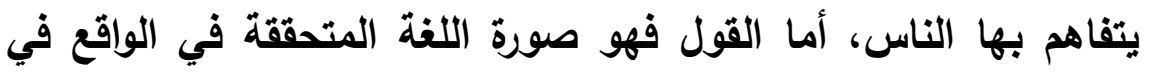
استعمال فرد معين في حالة معينة التحليل، وهذا الاستعمال يطابق النظام العام للغة في صفاته الأساسية، ولكنَّه يختلف في تفصيلاته من فرد إلي في آخر، ومن حالة إلي حالة، فلكل فرد من المتكلمين طريقته الخاصة. وهذه

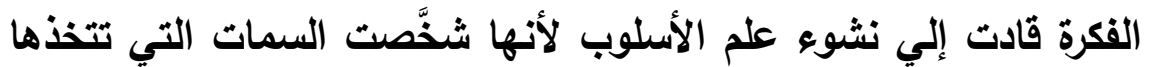
اللغة في الاستعمال، وهي التي تكون ما سمّاه أهل الأدب الأسلوب. (10) الثانية : أن الاختلافات اللغوية ترجع في الغالب إلي اختلاف المواقف، فاللغة بوصفها نظامًا اجتماعيا تأخذ أثكالا متعددة، وهو ما يجعل لكل فئة الكات من الناس طريقتها الخاصة في استعمال اللغة، ومن أبرز عوامل الاختلاف : الجنس، العمر، المهنة والبيئة الاجتماعية، والمناسبات

الاجتماعية والمواقف تتطلب في بعض الأحيان أداءً لغويًا مناسبًا لها. إن هذه الاختلافات وغيرها تثترك في تكوين الموقف الذي يحاول القائل ان يراعيه فيما يختار من طرق التعبير حتي يستطيع أن يوصل ما يريده إلي شخص آخر أو جماعة من الناس، فهو لهذا يتخير طريقة التعبير

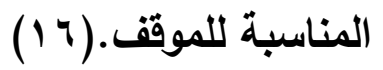




\section{دكتور/ علي عبد الظاهر علي عبد اللطيف}

قصبدة الشهيد :

هذه القصبدة بمنزلة وعد قطعه الشاعر على نفسه، وقا صدق الشاعر

$$
\text { ربَّه وعده : }
$$

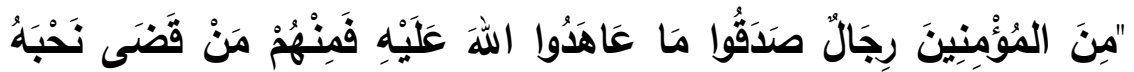

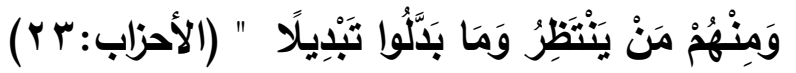

فهي قول صادقه العمل، وكأنه يرثي نفسه قبل موته بنحو تسع سنوات . وشاعرنا لم يخلِّف لنا ميراثًا كبيرًا من الأقوال والأشعار، لأنه عرف أنَّ الكلمة فعل، وهو لم يُخلق ليقول إلا ما يودُّ أن يفعله، فهو قد فعل وصدق قوله فعله .. وكم من شاعر ملأ الانيا صياحاً بحلاوة لسانه ويروغ عند الفعل كما يروغ الثعلب، في حين لم يترك لنا شاعرنا الثهيِ سوى ديوانٍ صغير، صفحاته ثلاث وثلاثون صفحة، تضم في قلبها سبعًا وعشرين قصيدةً هي كل ما خلَّقته قريحة الثهيد. أكد أحمد عبد الرحمن، أحد رفاق عبد الرحيم محمود، أنه قال هذه القصيدة في ثوره فلسطين عام ( بس 9 1)، وقد أنشأها ليرثي أحد رفاقه من الاروز الأين قتلوا أثناء الدفاع عن الأرض والمقدسات، فراح ينشد القصيدة، (V) وهي تفيض حزناً، وتحثٌ على مواصلة درب الجهاد ومقارعة الصهيونية والمستعمرين، وقا طبقت شهرتها الآقاق لصدقها الفني ويساطة أسلويها، حتى فاقت شهرة مؤلفها نفسه، وما اشتهر منها على الأخص أول بيتين فيها، يقول في قصيدته :

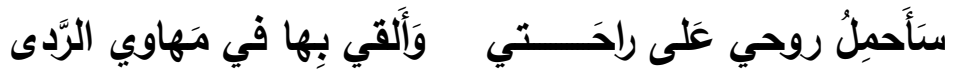

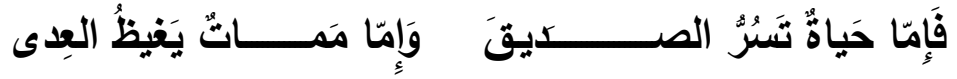

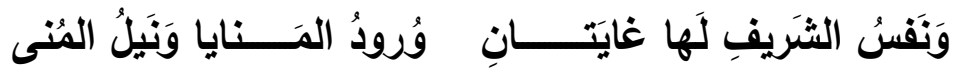

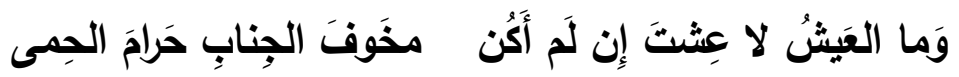


قصيدة (الشهيا) لعبد الرحيم محمود قراوة أسلوبية

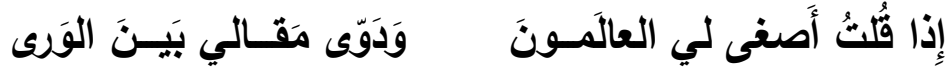

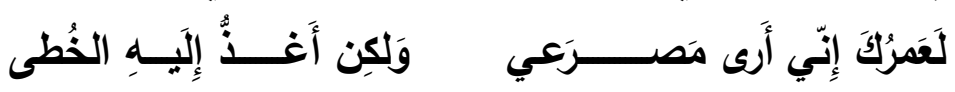

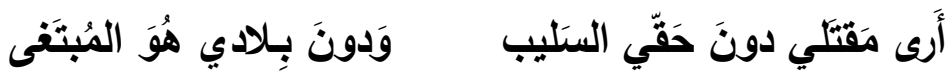

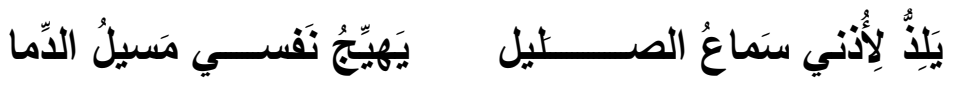

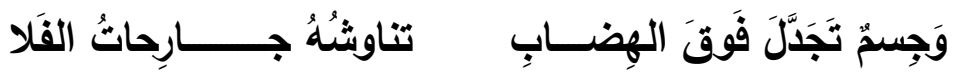

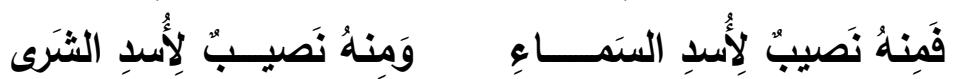

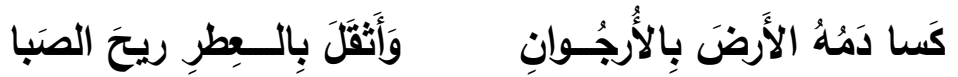

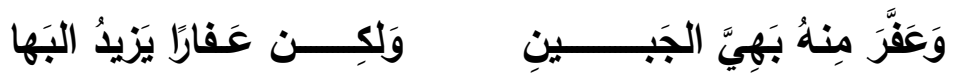

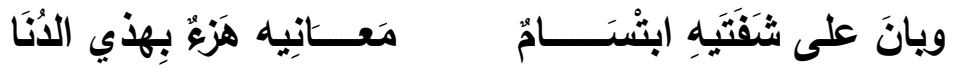

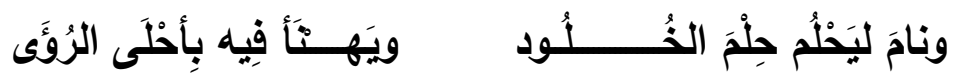

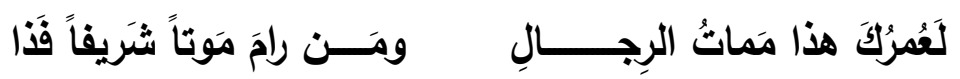

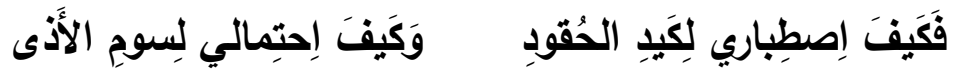

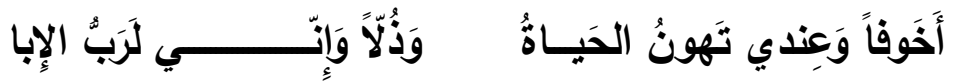

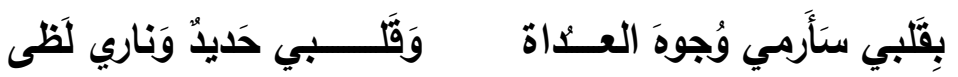

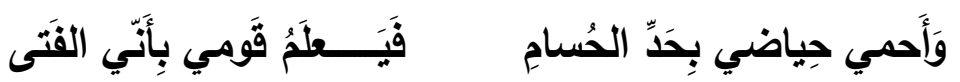

التحليل

إذا اتفقتا مع بارت على أنَّ النص نسيج، وفيه فكرة توليدية يتخذها النص لنفسه، وينشظل بها من خلال تثبيك دائم، وأن الذات إذا تكوَّنت ضائعة

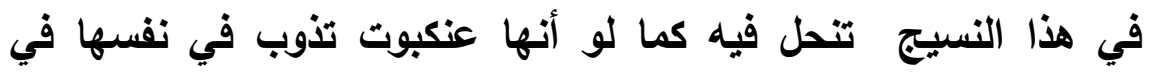

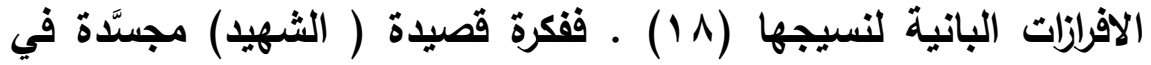
إثبات هذه الحقيقة المعنونة من قبل الثاعر، والتي حاول إثباتها على الثيات طول بنية النص الثعري مؤكلًا إصراره على تحقيق هدفه السامي غير فيل

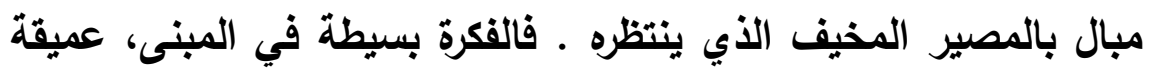


في المعنى. دلَّ عليها عنوان القصيدة، ذلك العنوان الأي أضحى في الثعر الحديث حلقة أساسية ضمَّت حلقات البناء النصي، وأصبح بالإمكان أن نتحدث عن العنوان كحيثنا عن النصوص، فالعنوان آخر ما يكتبه المبدع وأول ما يتلقفه المتلقي، فهو يمثل رسالة قصيرة موجزة بفحوى المضمون. " ويقدم معلومات أساسية لفهم النص وسياقاً يسهّل للقارئ ترسيخ المسألة المركزية للنص في الأكرة واسترجاع المعلومات عن طريق تنشيطه، منذ الشروع في القراءة، وقد صيّرت المناهج النقدية الحديثة مثل السيميائية - للعنوان أهمية خاصة أطلقت عليها (علم العنونة) ورائدها الناقد الهولندي (ليوهوك)، وأدرج ضمن عناصر أطلق عليها:جيرار جينيت - تسمية:- (النص الموازي) او (عتبات النص) (9 ( ) وقد جعل (أندريه جاك ديشين) العنوان ضمن ما اسماه (المنظمات التمهيدية) وهي معلومات أو نشاطات قبل قراعة النص ( • ( ). والعنوان يقوم بجملة وظائف في النص، تتمثل في التعيين والإغراء والوصف والإيحاء وغيرها، به يستطيع المبدع لفت انتباه المتلقي إلى نصه، ومن ثمّ يفتح شهية القراءة لايه (Y) (Y). وفي أحيان كثيرة يكون عنوان القصيدة محور علاقة عكسية عند المبدع والمتلقي، فهو عند المبدع آخر ما يكتبه، ولاى المتلقي هو أول ما يقرؤه، ويهذا تكون نهاية

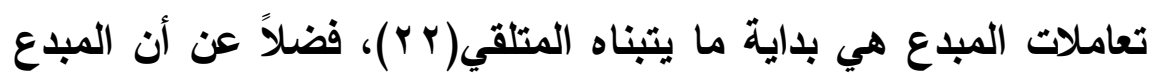
(飞) رافع يحيى : الإشر اقي والأرضي في شعر البياتي، بيروت، لبنان ص (0) عبداله الغذّامي: ثقافة الأسئلة مقالات في النقا والنظرية ، دار سعد

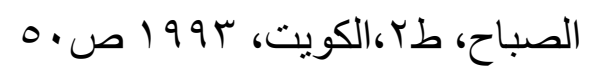




\section{قصيدة (الثشهيا) لعبد الرحيم محمود قراءة أسلوبية}

يضع جوهر نصه في العنوان من خلال تكثيفه، أما المتلقي فإنه يبسط مساحة التأويل في العنوان ليصنع منها شكلاً مفترضاً للنص قبل قراعته، متجاوزاً المثيرات المباشرة فيه، فأول ما يتلقفه المتلقي هو كلمة الثهيد، وهي رسالة موجزة مركزة هيأت السامع إلى أنه سوف يقراً عن مقتل إنسان في سبيل قضية ما، لم يعرف غالبية القراء ملابسات القصيدة أو مناسبتها وسبب تأليفها إنما هي قصيدة تحمل عنواناً يوحي للوهيلة الأولى بجو جنائزي يثير الثجن، ولا شك أن القارئ أيضًا مدعو للمشاركة الوجدانية بهذا العرس الجنائزي حيث يُحمل رجل ذو قضية إلى مثواه الأخير تصحبه الدعوات والأحزان لفقدان شخص ناضل حتى لفظ أنفاسه، فما تلقفه المتلقي كلمة الثهيد ذلك الذي مات في سبيل قضيته دون

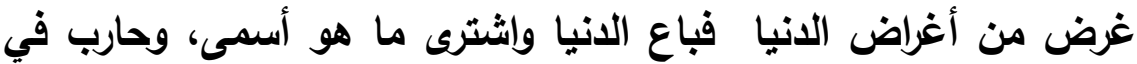

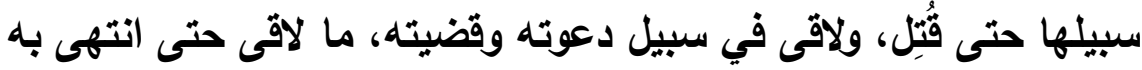

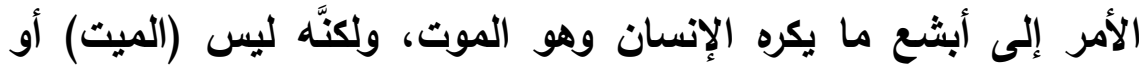

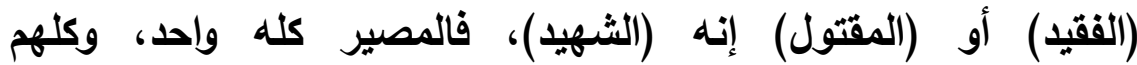
سيتساوون تحت التراب، ولكن الثهيا لم يمت إلا لقضية تتناسب وحجم تضحياته، فأي قضية تلك التي مات لأجلها ؟ كل هذه الأفكار أثارت ذهن

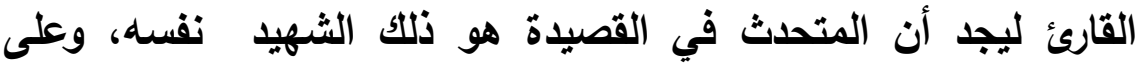
لسانه : (2)

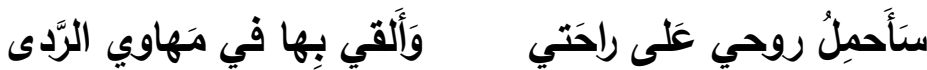
فهذا مطلع القصيدة، والمطلع كما قال النقاد القدامى : " مُفتَتَحْ الكلام

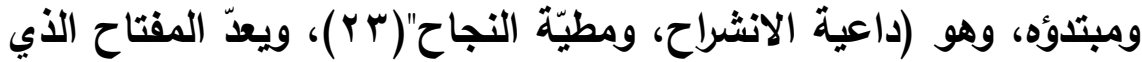
ييسّر في ذهن المتلقي مجالاً لما يليه من أبيات، ويكون تأسيساً لها، وهو ولئه الذي تُُنَّفَّ منه طبيعة القصيدة وعنوانها وغرضها ووزنها وقافيتها، 


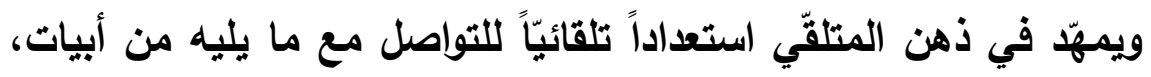

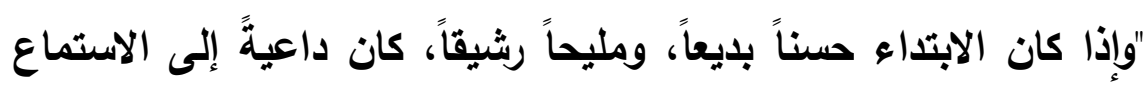
لما يجيء بعده من الكلام" (؟ ب).

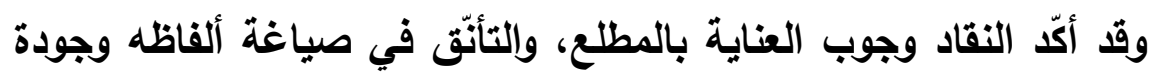

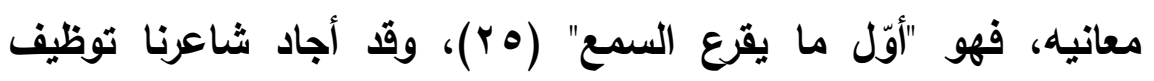

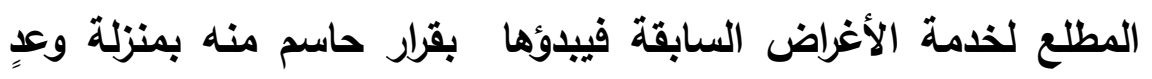

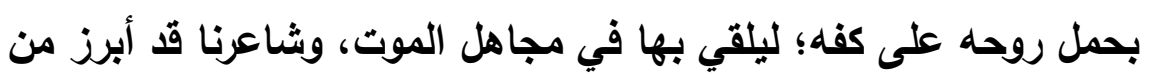

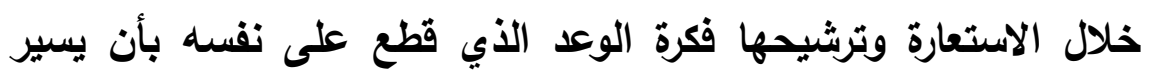

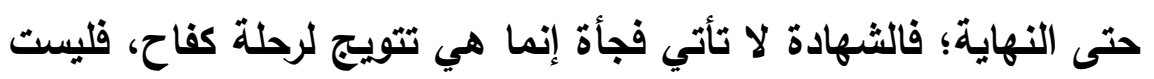

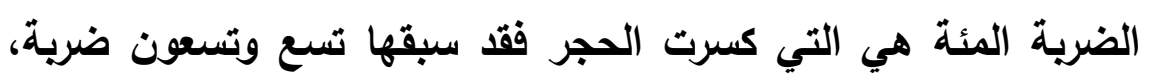

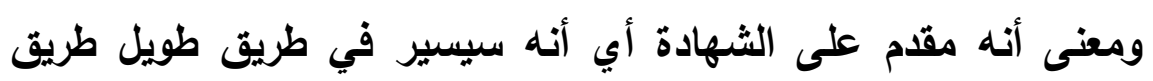

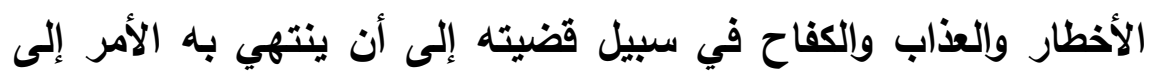
المصير المحتوم، وهو يتناص مع إبراهيم طوقان في قصيدته" الفدائي " :

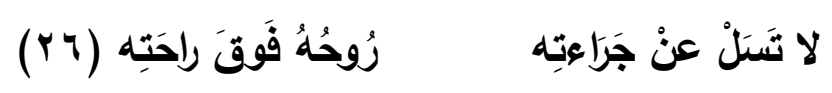

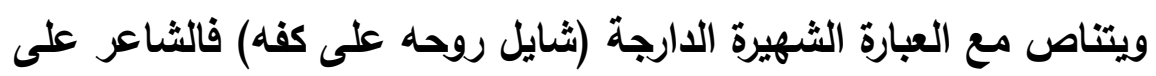

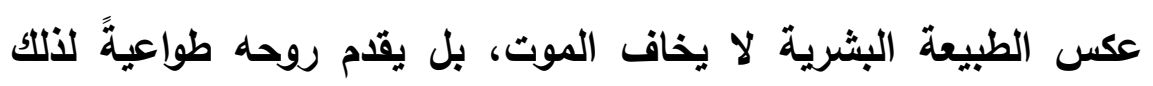

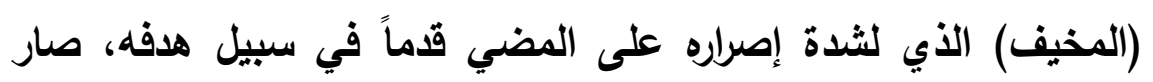

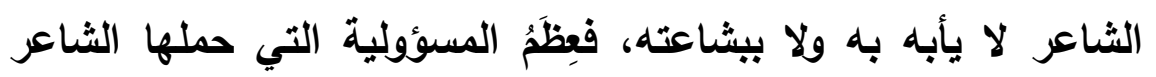

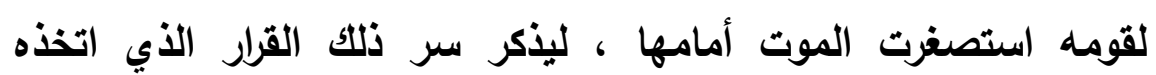
بالمضي في جوف النار بقوله :

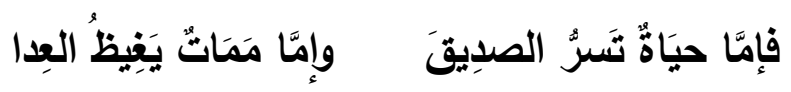

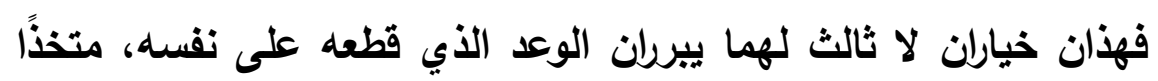

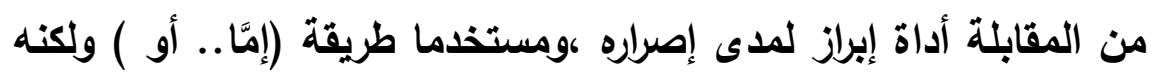




\section{قصيدة (الثشهيا) لعبد الرحيم محمود قراءة أسلوبية}

للوزن كرر (إمَّا) وهي من طرق الإجمال فصَّلها ما بعدها فحققت معنى

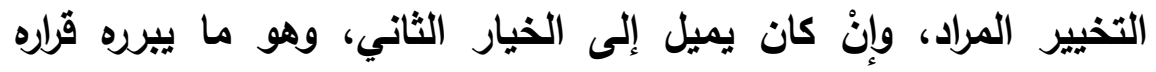
السابق وهو يعمق أكثر من مستوى للوعي بإرسال ثلاث رسائل :

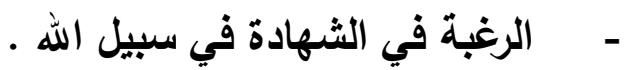

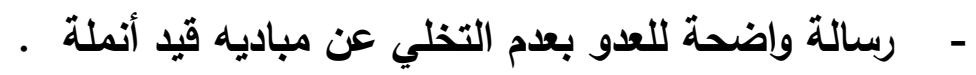

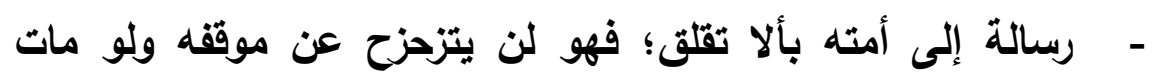

ويبدو أن قد أعجبته فكرة حصر الحلول في الثنائيات فيعاود استعمالها عن طريق الإجمال والتفصيل فنفس الثريف تجنح إلى غايتين يتناسبان

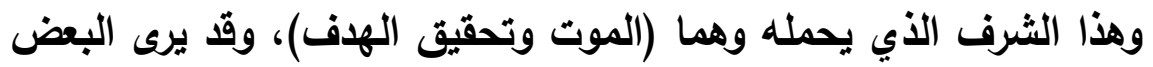
أن الأفضل له تقديم (المنى) على (الموت) على أساس أن تحقيق المنى النى

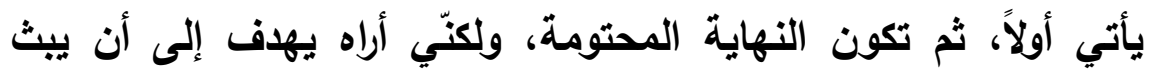

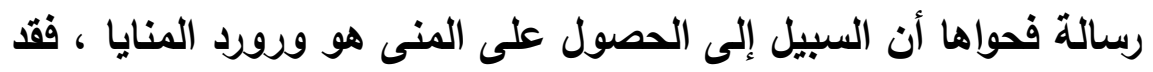

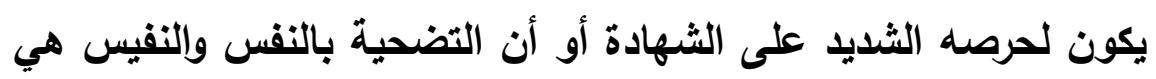
أساس تحقيق المنى فيقول :

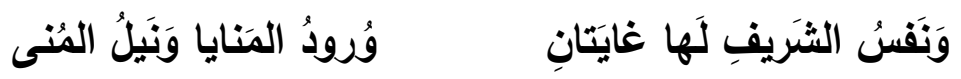
وقد يكون مغنى الواو هو الفيصل في هذه الإثكالية، فيرى فاروق مواسي

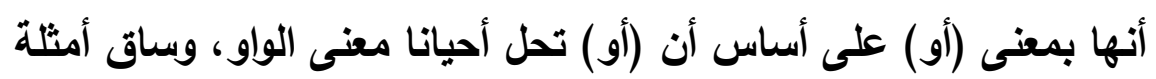

$$
\text { كهيرة لذاك . (rV) }
$$

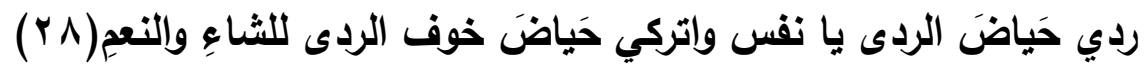


فالمتنبي ينصح نفسه بأن تأتي حياض الموت وتثرك الخوف للجبناء كالثاء والأنعام، بينما ينفي شاعرنا عن نفسه التهمه بأن حصر غاية الشريف، وهو يقصد نفسه في الموت في سبيل تحقيق الأماني والأهداف. ولا شك أن تكرار حرف النون أضفى على البيت موسيقى تحمل الإحساس بالأنين والحزن، وهو ما يتوافق مع الحال الجنائزية التي حملت أبيات

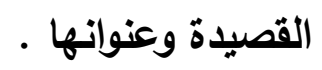
وكذلك ساهم الجناس بين (المنايا) و(المنى) في إضفاء جرس داعب الأذن برنة موسبقية محبية إلى النفس، وتقسيم البيت إلى وحدات موسيقية باستخدام وحداث ثنائية رفع حدة الموسيقى التي تحمل إحساسا

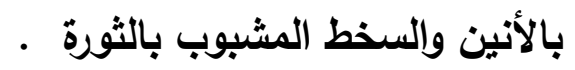

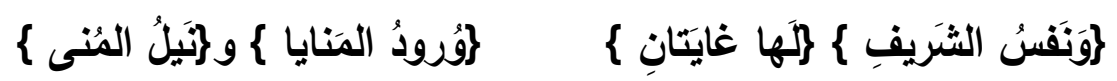
ثم يوضح تفضيله لخيار الموت بأن العيش لا قيمة له إلا إذا عاش بكرامة يرهبها الأعداء وتحفظ له عزة النفس:

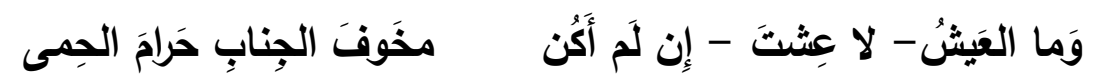
قد ساهم التقديم التأخير في عملية قصر جميلة فهو يقصد : إن لم أكن مخوف الجناب حرام الحمى فما العيش إذن ؟ وترتفع نبرة الثورة والإصرار على مجابهة تحدي الموت بالجملة الاعتراضية (لاعشتَّ) ثم يفصل روئيته بعدما أجملها في البيث السابق بالبيث اللاحق :

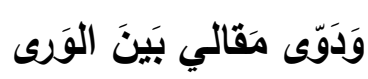

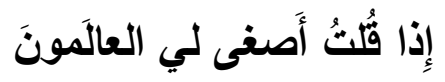
فكلمته لابد مسموعة ولها حضورها في العالم أجمع، ففعل الشرط (قلت) هنا بلا جملة مقول قول بمعنى تكلمت جاء بعده جواب الشرط مباشرة (أصفى)، فقد ربط بين السبب والنتيجة بأسلوب الشرط مستخدمًا (إذا) 
وهي أداة شرط للتأكيد، فهو لا يحتاج جملة مقول القول؛ لأنه بمجرد أن

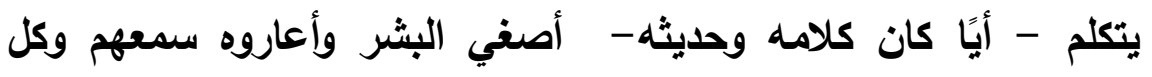

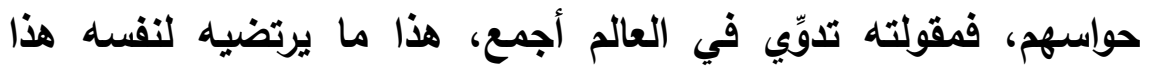

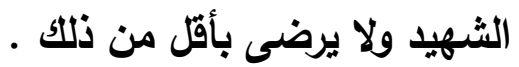
وهو هنا يتناصّ في المعنى مع قول المتنبي :

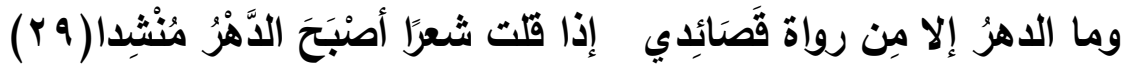

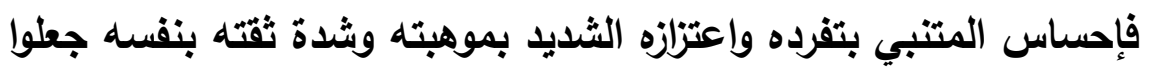

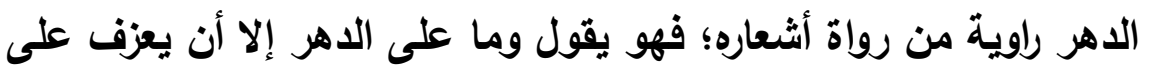

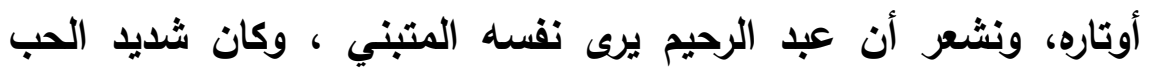

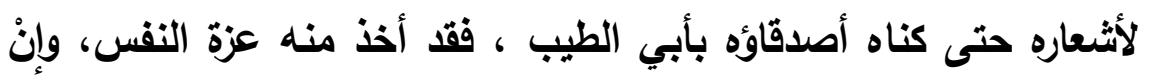
كانت العزة لاى عبد الرحيم تنحو منحئً آخر في اتجاه وطني قومي، فهو

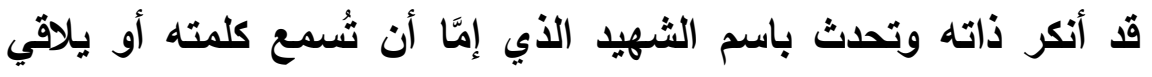

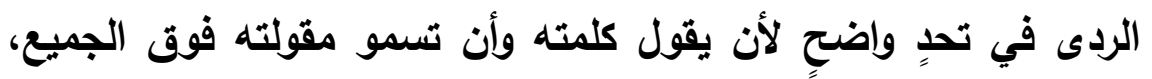

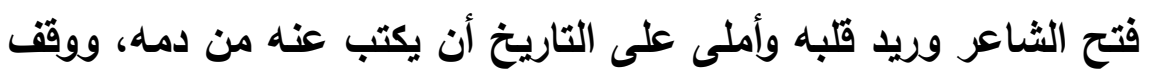

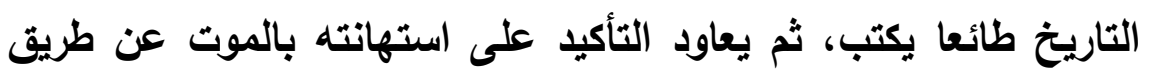

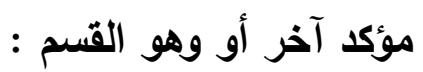

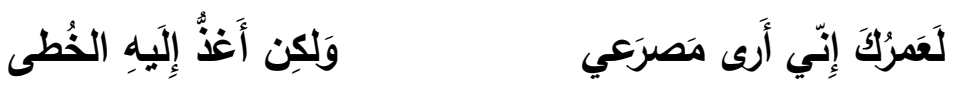
فيقسم على أنه على يقين من الموت، ورغم ذلك يسير إليه بخطى حثيثة،

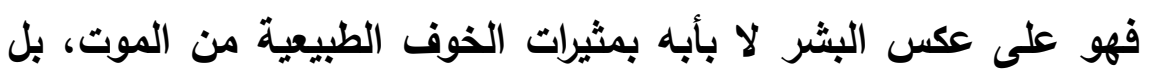

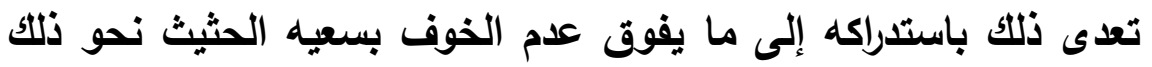
المجهول المخيف، نلاحظ استخدام المؤكدات باختلاف أنواعها (إذا)

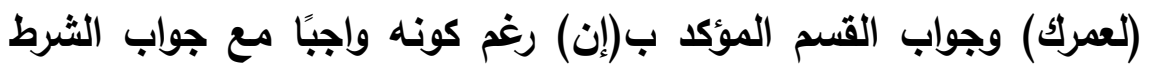

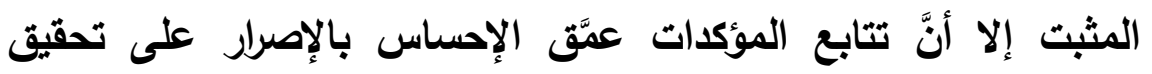


الههف وعدم مبالاته بالموت، تضافر ذلك بتخصيصه المصرع لنفسه بياء المتكلم، ما أعطى إحساسا باليقين من مصيره المحتوم .

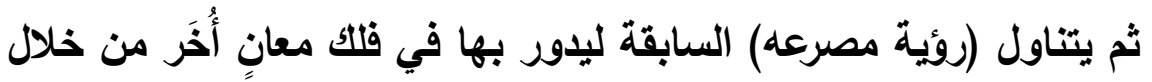
روئية ثانية لألك الموت فقا وضعه في مقابلة بينه ويين الحق السليب، فإمَّا هذا أو ذأك : أَرَى مَقتَّلي دونَ حَقِي الستليب فإعادة الحق السليب لبلاده أو الموت خياران يترددان بينه وبين الموت بإضمار طريقة (إما .. أو) فإما عودة الحق لأصحابه أو يلقي نفسه في

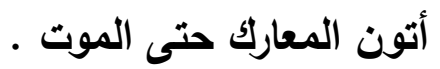
ويما أنه شهيذ معركة الحرية والكرامة فهو يطرب لسماع صليل السيوف ويلذ لمسيل دماء الأعداء:

يَلِّْ لِأُنْني سَماعُ الصَّليل وإن كان على مستوى الحقيقة لا سيوف هناك، بل آلات حرب ودمار، ولكنه استخدمه كرمز غاب المروز عنه ليأتي بصوتّه مثثلاً عنه فيما نطلق عليه مصطلح التمثيل الصوتي للمعاني (·r) فقد وضعنا في قلب المعركة كأنتا نسمع ضريات السيوف وهي تصطك ببعضها البعض محدثةً صوتًا محبيًا لاى الشاعر، وتآزرت الصورة البصرية البشعة لمنظر مسيل الاماء مع الصورة السمعية في بث مشهر سينمائي أمامنا يعيدنا إلى العصور الوسطى حيث السيوف المتقارعة والاماء التي تتزف جرَّاءها، وقا وجد الثاعر نفسه في هذه البيئة القاسية المخيفة الحاشدة بالأخطار وهي مصدر سعادته بكونه مقاتلًا وكأنه ينطق على لسان عنترة :

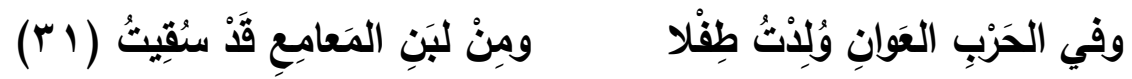




\section{قصيدة (الثشهيا) لعبد الرحيم محمود قراءة أسلوبية}

فعترة ولد وسط الموت فلا يخافه، وهكذا شاعرنا لا يخشى الموت فحب، بل إنه يطرب لسماع صوت المعارك ومشهـ الدماء . ثم يستأنف مشهر الحرب المحبب إلى نفسه :

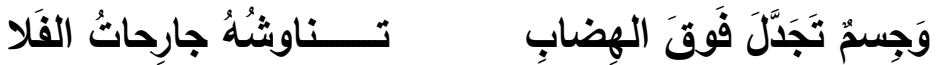

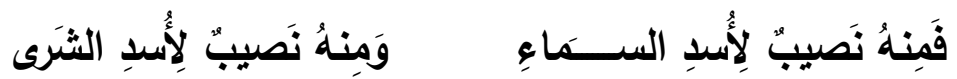

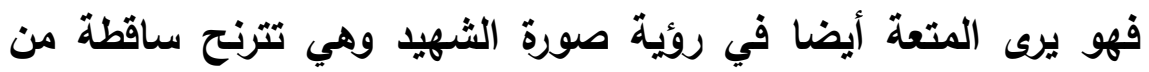
أعالي الهضاب، فتتلقفها وحوش الصحاري الضارية فتصعد الروح الطاهرة إلى أسد السماء (البروج) وأسد الأرض من نصيب الضواري تلتهمها التهاريا

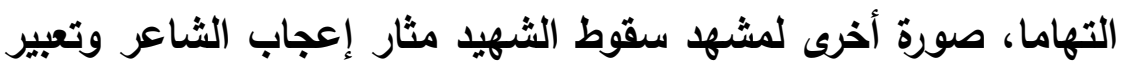

عن طموحه .الموت الحقيقي ، وقد أضفت موسيقى التقسيمة الثنائية :

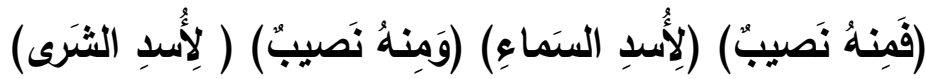
نغما رائقًا عمل على تثكيل اللوحة الموسيقية بنغمات عالية من خلال

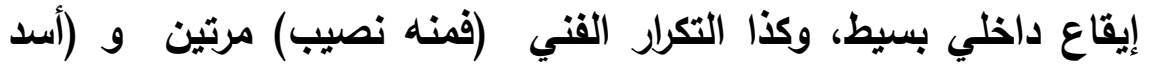
ال...) مرتين ساعد بتثكيله النفمى على رفع مستوى الموسيقى للبيت تآرزا مع الطباق بين منطقتي (السماء في الأعلى - منطقة الثرى في

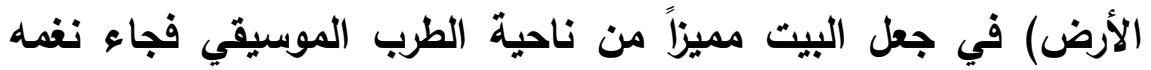
متسقًا رقراقًا له مفعوله وتأثيره الطيب في النفس ـ أما تأثير سقوطه على التى تلكك الأرض الطيبة التي دافع عنها بروحه : كَسا دَمُهُ الأَرَضَ بِالأُرُجُوانِ صبغت دماؤه الطاهرة الأرض باللون الأحمر القاني، وحمَّل ريح الصبا بالِ

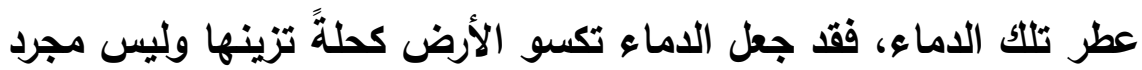

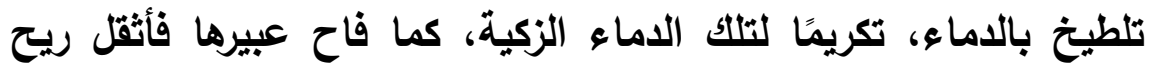

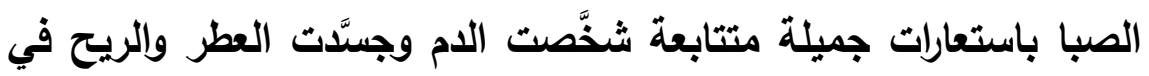


تثكيلة جميلة تتهيأ لتكريم تلك الاماء بما يليق بها ، وكأنه يتناص مع قول أبي تمام في رثاء محمد بن حميد الطوبسي :

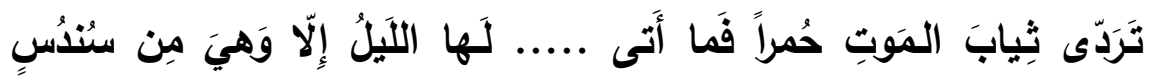

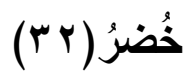
ولكنَّ أبا تمام جعله من يرتدي ثياب الموت الحمراء بينما شاعرنا جعل الأرض هي التي تلبس الثياب الحمراء.

وَلْكِن عَفْارًا يَزيلُ البَها

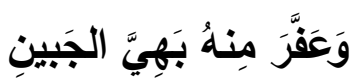

وتتاثرت تلك الاماء على الجبين فكانت كالتاج الأحمر الذي يزين جبهة صاحبه وزادته بهاء وإثراقًاً وجعل الجبين بهيَّا، ولكنَّ الدماء أضفت عليه بهاءً آخر استكمالا لتلك الصورة البصرية التي جعلتنا في عوالم حمراء داخل منظومة جديدة وممرات عميقة للاماء غير التي عهدناها واعتادتها مخيلتنا بخبرتها المتوارثة لمنظر الاماء الكئيب، فقد اجتمعت أربع حواس

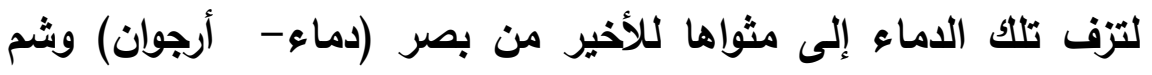

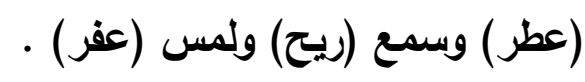
ويعاود تأكيا سعادته بهذه الشهادة فيقول فئول

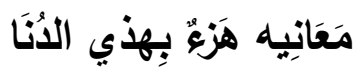

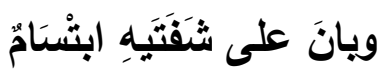
ترتسم الابتسامة على وجهه فترافقه إلى مثواه الأخير، وهي ابتسامة الظقر وتحقيق الأماني، وتحمل السخرية من هذه الانيا التي يتكالب عليها المستعمرون ويقتلون الأبرياء، وهي لا تساوي عند الله جناح بعوضة، فقد اشترى آخرته بهذه الانيا الفانية وعلم أن السلامة فيها ترك ما فيها، فترتسم ابتسامةٌُّ تلخص كل معاني الحياة الفانية التي أدرك كنهها فافتر ثغره عن تلكك ابتسامته الساخرة التي تحمل وعيا لم يدركه الحمقى. ثم يستسلم للحلم الكبير الأي وهب نفسه له : 


\section{قصيدة (الثهيا) لعب الرحيم محمود قراعة أسلوبية}

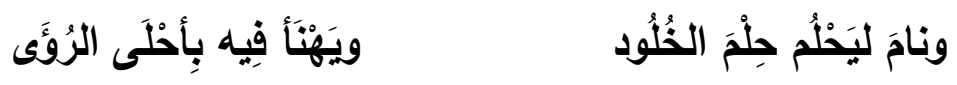

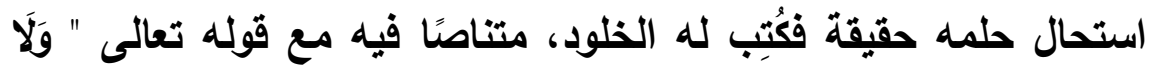

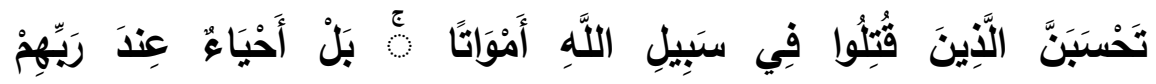
يُرْزَفَونَ"(آل عمران :

فإذا كانت الثهادة الدراسية تمنح الإنسان مركزًا مرموقًا فهذه الثهادة الثاد

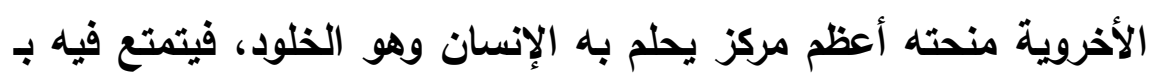

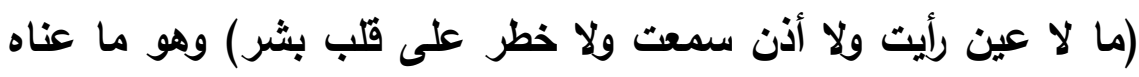

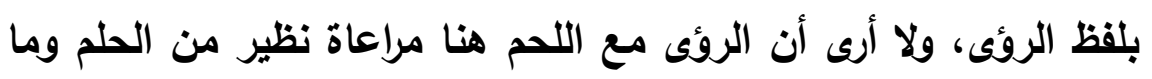

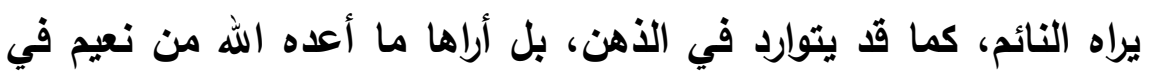
الجنة، فهو يقصد الروئية البصرية وليست الروئة الحلمية فيما يراه النائم.

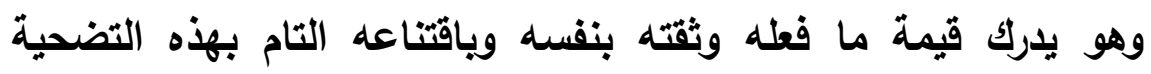

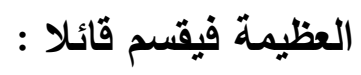

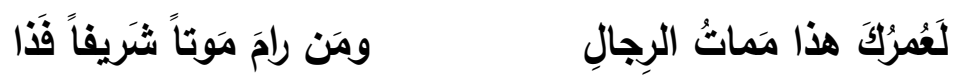
هذا ما يليق بمن يحمل لقب رجل، نشعر كأنه يلعب على أوتار مقولة لئل

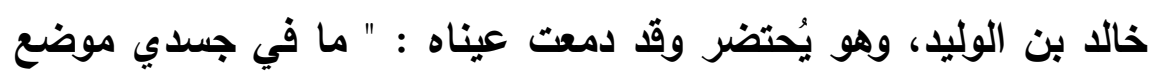

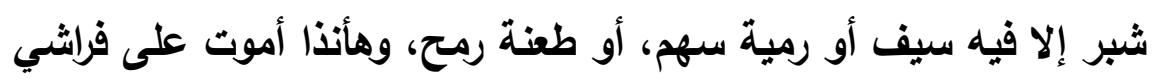

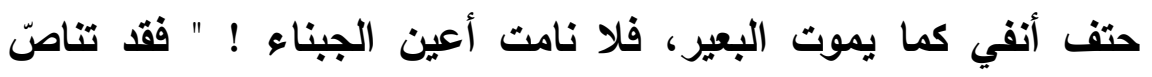

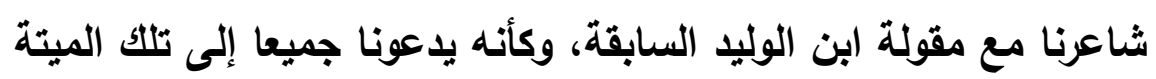
التي تمناها خالد بن الوليد لنفسه ولم ينلها، واستخدام الجملة الاسمية الولية

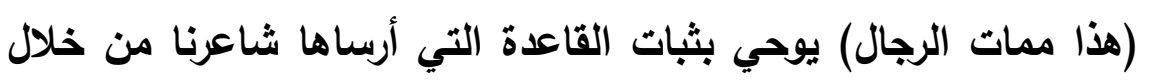

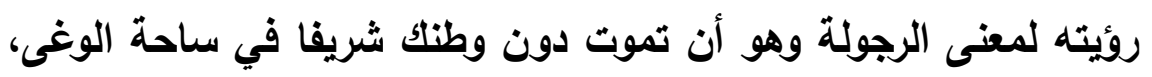

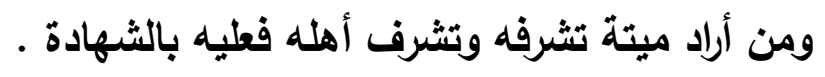

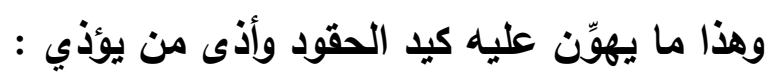

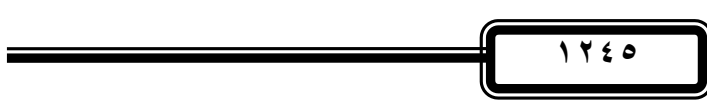




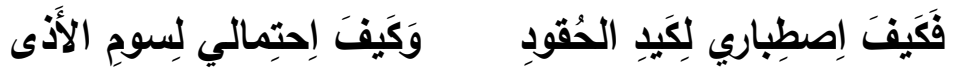

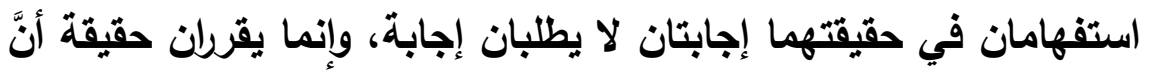
الموت هو من جطله يصبر على كيد الحسود وتحمثل أذى العدو يدل عليهما ما جاء بعدهما من سؤال :

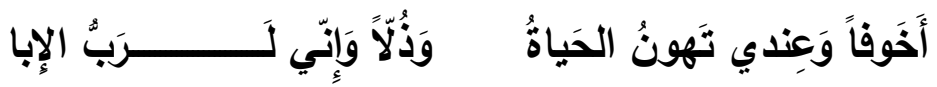

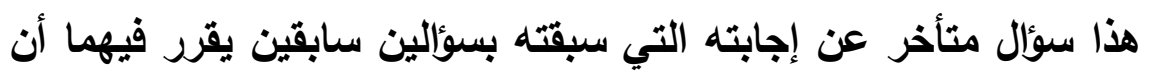

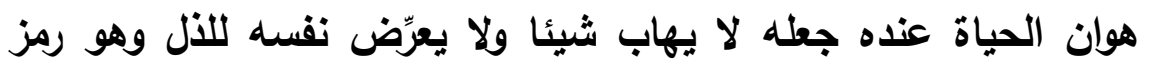

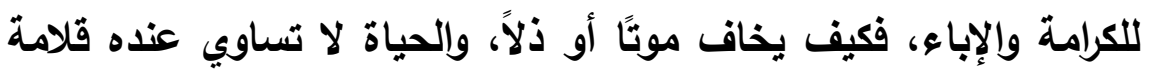
ظفر بإبائه وحرصه على الموت، وهو ما جعله يصبر على حقا عدوه

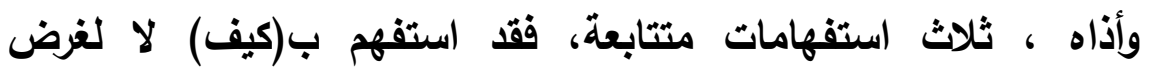
التساؤل، بل تقرير فكرة أنَّ حرصه على الموت هوَّن عليه كل المشاق

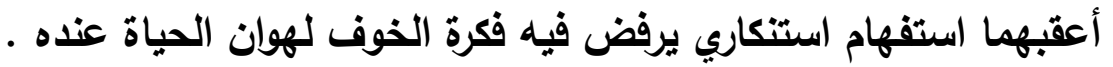

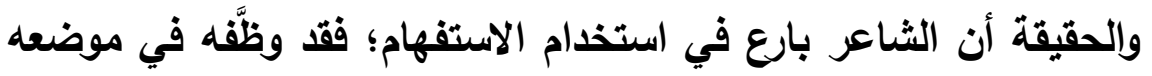

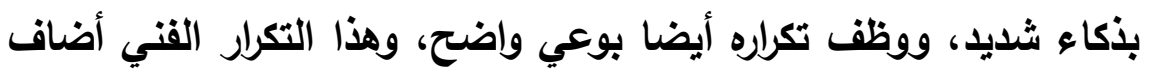
وعيًا جديًا لاى المتلقي وأجاب عن تساؤلات ريما قد تكون أثارتها

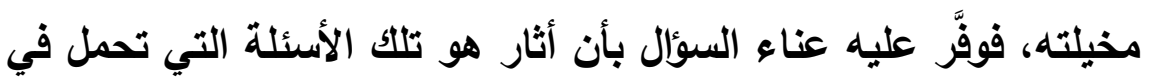
طياتها إجاباتها، فكأنه يرد على المتتبي ويقول له : قد سمعت بنصيحتلك

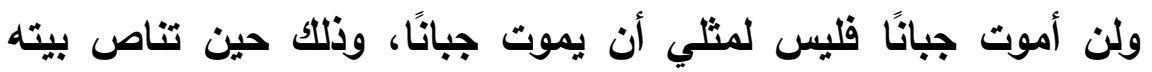
الأخير مع المتتبي في قوله الثهير :

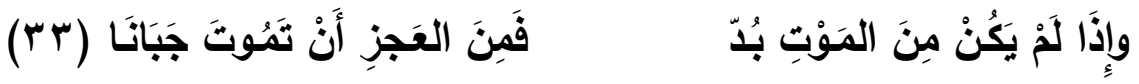
ثم يقرر في بيته قبل الأخير بأنه : 


\section{قصيذة (الثشيش) لعبد الرحيم محمود قراءة أسلوبية}

$$
\text { بقََِبِي ستَأَمي وُجوة العُداة }
$$

قلبه الصامد القوي الذي يحمل مشاعرة النبيلة تجاه وطنه وإيمانه بقضيته وفئه جسَّده الثاعر في صورة حديدية نارية تحمل الغضب الذي الثتعل بقوة تحترق بداخله فتصبح كتلة كالقتبلة التي ترمى على الأعداء فتكون

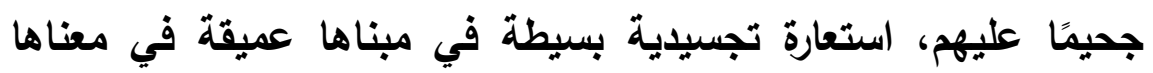
وتثبيهان للقب بالحديد والنار باللظى في ثلاث صور ثورية توحي بقوة فئا

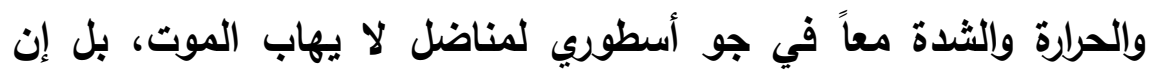

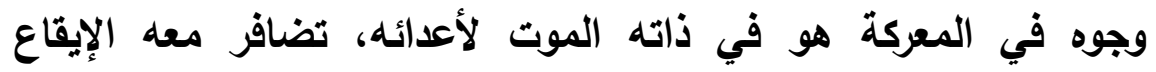
الاخلي الذي أبرزته الثنائيات التقسيمية :

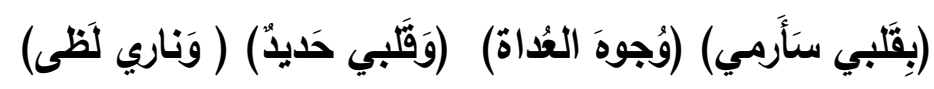

في إبراز مغنى الإصرار والتحدي على المضي في هدفه بقتال الأعداء

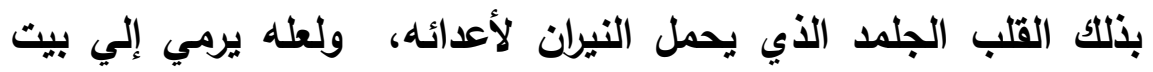
عنترة متناصًا معه في قوله :

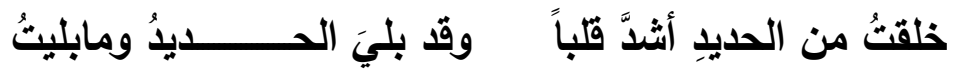
فقد حمل قلب عنترة المقاتل المغوار الذي لا يشثق له غبار وقلبه من حديد لا يبلى، كما يتناص مع قول المتنبي :

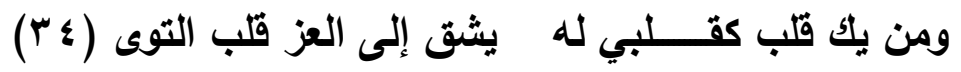
وينهي قصيدته بالقرار الأخير :

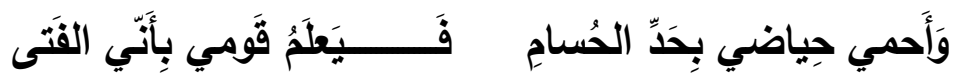
يمثل البيت خاتمة القصيدة، يُعدُّ (الانتهاء) أو (الخاتمة) المطلب الأخير

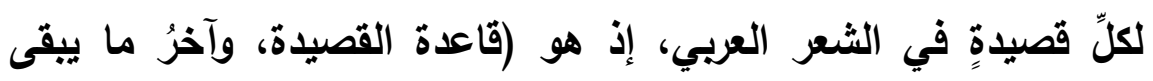

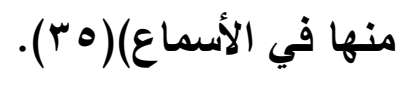




\section{دكتور/ علي عبد الظاهر علي عبد اللطيف}

فعلى الرغم من طَرَفيَّتها إلا أنّها تُشكّل عنصراً مهمّاً في أقسام القصيدة العربية، لِما فيها من معطياتٍ تتجلّى فيها روح القصيدة وخلاصتها الأهنة، وما توصل إليه الشاعر من خلال تسلسل الأفكار التي طرحها في ما سبق الخاتمة. وليس بعيداً أن تُحفظ من بين سائر أجزاء القصيدة،

$$
\text { لقرب عهt السامع أو القارئ بها(؟ ب). }
$$

فقد قرر أنه سيحمي أرضه بسيفه، وتكون النتيجة أن يعلم قومه من هو، فالفتى من قال هأنذا، واطلاق الكلمة على عمومها دون وصف وتعريفها ب(أل) أطلقت كثيرًا من التساؤلات حول كنه ذلك القتى، فهل القتى بمعنى القتوة والقوة، أم تتاصّ مع ذكر الفتى الذي عناه الإمام علي بقوله : ليس القتى من يقول كان أبي الكن القتى من يقول هأنذا (rv) أم يقصد القتى العربي أم يقصد فتى الإسلام ؟ كلها تساؤلات أثثارتها كلمته الأخيرة، وكأنه لا يريد أن ينهي قصيدته بنهاية مفتوحة، تلك القصيدة ذات الطابع السردي حيث يحكيها شاعرنا بضمير المتكلم (أنا) وينهيها بـ (أني (الفتى) ، ولا يمنع أن يكون البيت متناصا مع قول المتنبي :

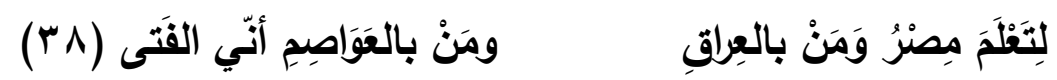
ففي عطف العام (العواصم) على الخاص (مصر والعرلق) نجد أنه أجمل الأمة كلها فالمتتبي يريد أن تعلم أمته من هو وهذا يدور في فلك ما جاء باه شاعزنا . مستويات التحليل المستوى الصوتي: - - الجانب الوظيفي الفونولوجي يرى بعض اللسانيين أن الإيقاع الصوتي ينشأ من "الإعادة المنتظمة، داخل السلسلة المنطوقة لإحساسات سمعية متماثلة تكوّنها مختلف الإع 


\section{قصيدة (الثشهيا) لعبد الرحيم محمود قراءة أسلوبية}

العناصر النغمية (rq) أي أنَّ أهم المؤثرات الصوتية التي تحدد ملامح

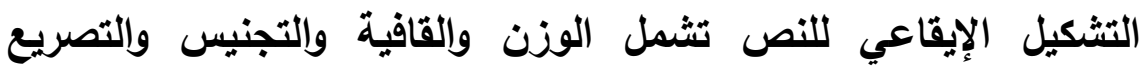
والتقسيم والتكرار والترديد، والتوازي التركيبي التي ينثأ منها نوع من لناعن التماثل الوزني والتعادل الصرفي بين بعض أجزاء النص، وغير ذلك من

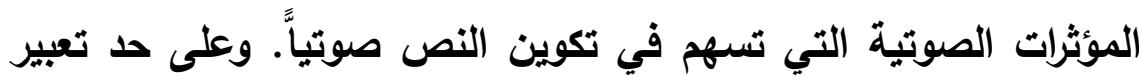
آي ريتثاردز فإنه "إذا كان الوزن الثعري ينبع من تآلف الكلمات في علاقاتٍ صوتيةٍ لا تنفصل عن العلاقات الدلالية والنحوية؛ فإن القصيدة في هذه الحال تستمد إيقاعها من مادتها أي من اللغة، ومن موسيقي تثكيليةٍ مجردةٍ تعتمد على التناسق الصوتي للكلمات في إطار الوزن فين الشعري، بطريقة تُكَّن الكلمات من أن يؤثر بعضها في البعض الآخر

$$
\text { علي أكبر نطاقِ ممكنٍ (• ع ). }
$$

وقد قَّمت الدراسات الحديثة موسيقى الثعر قسمين، هما : ـ الموسيقى الخارجية، وقوامها الوزن والقافية. ـ الموسيقى الداخلية، والتي تتمثّل . في الأغلب . بالمحستّات البديعية والتقسيمات الإيقاعية المتوازنة وما شاكلها ( ( )). أما عن مكونات الإيقاع في النص الثُعري فهو "يتكون مما نسميه بالإيقاع الداخلي المؤكد للحركة، ومن النغم الخارجي ومن التتابع اللفظي

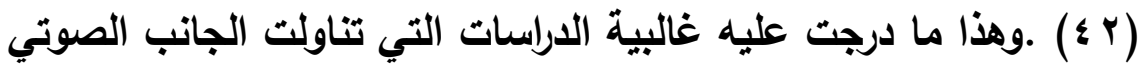
في النص الأدبي حيث تعتمد في مجلها على معالجة المكونات الصوتية في النص الثعري معتمدةً في تقسيمها على قسمين : خارجي وداخلي،

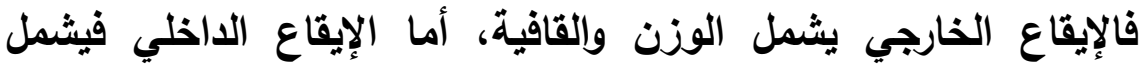
المظاهر الصوتية التي تولد المتواليات الصوتية والجرس الموسيقي داخل النص مثل التكرار والتجنيس والتقسيم وتوازي التراكيب وغيرهم . 
"فالإيقاع الموسيقى ينشأ من نسق التعبير، فحين يختار الثاعر ألفاظاً بعينها ويؤلف بينها وينظمها في إطار القصيا فإن ذلك ينتج عنه تناغم مميّز في الحروف والحركات، ويتضح ذلك في السجع والجناس وتكرار الكلمات والحروف، وكذلك تكرار الصيغ أو ما يسمى بالتراكيب المتوازية. وهذه الموسيقى الاخلية تكوّن نغماً خفياً يحسه به المتلقي عند قرائه للعمل الأدبي " فليس الثعر في حقيقته ليس إلاّ كلاماً موسيقياً تثفعل بهل لموسيقاه النقوس، وتتأثر بها القلوب " (بـ) إن الايقاع الاخلي للنص الشعري يؤدي دوراً أساسياً في سبك بـنى النص، وترابط أجزائه. وإضافةً إلى ذلك فالإيقاع الداخلي يؤدي دوراً مهماً في التأثير على المتلقي.(ع ؛ ) كما أنه عاملٌ مهمٌ في توليد الدلالة داخل

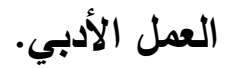
والإيقاع الداخلي شخصي ومتغير، ويخلو من المعيارية (0؛) .ولكل قصيدة نظامها الإيقاعي الداخلي الخاص بها، وهذه البنية الإيقاعية لا يمكن رصدها إلا بقراءة القصيدة قراعة داخلية كاشفة، تكتثف أعماق النص وطاقاته الإبداعية الخلاقة. وهذا ما يجعل من دراسة الجانب الإيقاعي عملية تعتمد كثيراً على التأمل والتأويل.

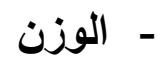

$$
\text { القصيدة على بحر المتقارب : }
$$

فعولن فعولن فعولن فعولن فعولن فعولن فئن

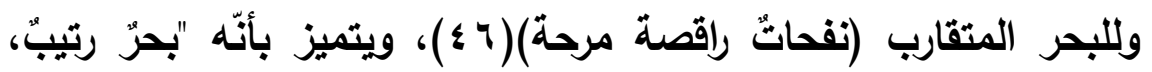
ولكنّه متدفّقّ سريع تأتي رتابته من وحدة التفعيلة (فعولن)، ويأتي تدفقه وسرعته من قصر هذه التفعيلة الخماسية..." ( v). 
إنّ التكرار الذي تفرضه تفعيلات المتقارب جعل الكثير من الشعراء الفحول يتفادونه ولا ينظمون عليه، إلآّا أنّ منهم من نظم وأجاد أيّما إجادة، كالأعشى والخنساء والمتنبي.

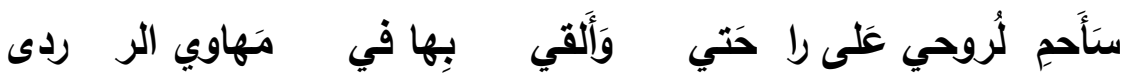
|| ||

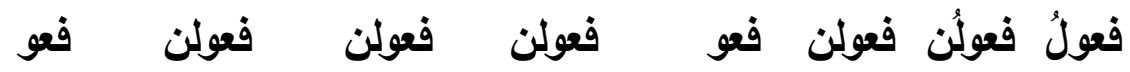

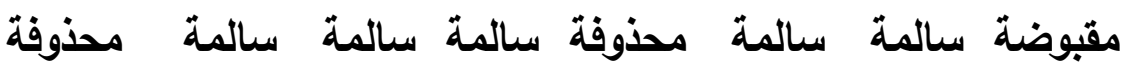

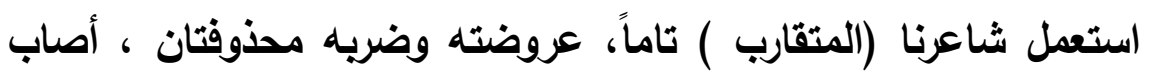
حشوه زحاف القبض وهو مستحسن في التفعيلة الأولى .

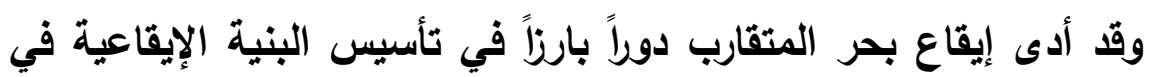

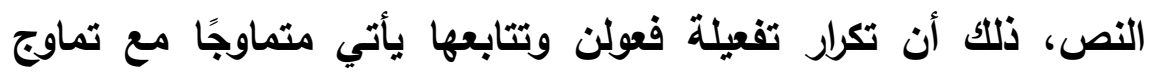

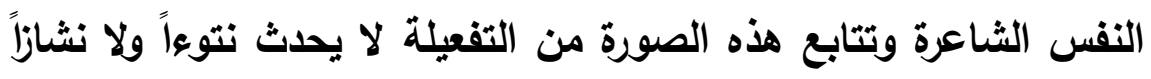

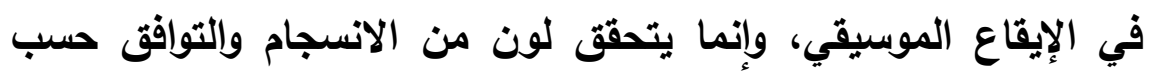
السياق الثعري والتدفق الثعوري. ومن خصائص بحر المتقارب الغنائية قدرته على الكثف عن التجارب

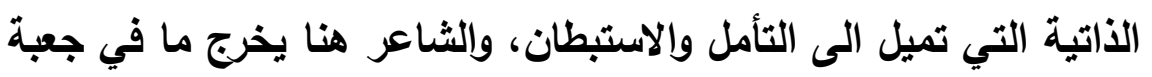

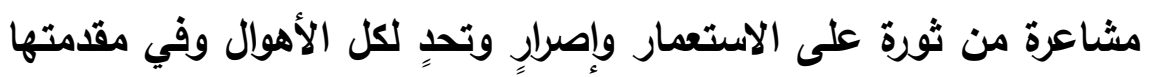

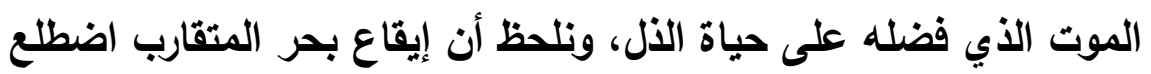

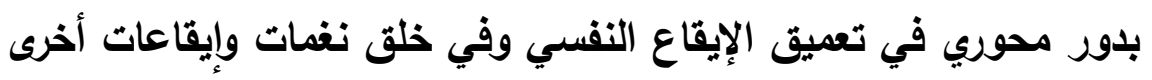
تتوافق مع الإيقاع الخارجي. فق كثر فيه التناغم الموسيقي الجميل

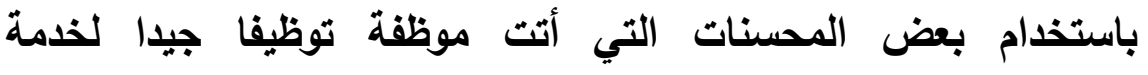
الموسيقى الاخلية التي عبرت عن فحوى نفسيته ويتضح ذلك من خلال

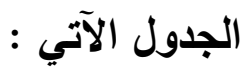




\begin{tabular}{|c|c|}
\hline عدد مرات وروده & المحسن البديعي \\
\hline 4 & الطباق \\
\hline 1 & المقابلة \\
\hline 3 & الجناس \\
\hline 6 & حسن التقسيم \\
\hline
\end{tabular}

وكان قليلاً فلم تكن غايته فقط إبراز الأشياء وتقيضها، بل عَكَسَ أيضًا الخطاب السردي الذي بدأه بالضمير المتكلم (أنا ) وتناغم في الأفعال الدالة على هذا الضمير، ولم يعدل عنه الا في بيتين أو ثلاثة إلى الضمير

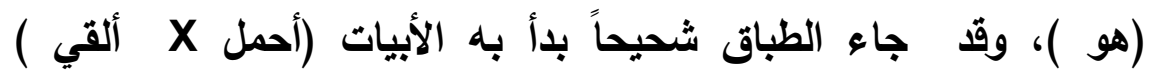
كمستهل لتزعته وقراره الأي اتُخِذ في صورة (وعد) ذلك المتمثل في الارتقاء بروحه إلى الحمل إلى أعلى ثم النزول بها إلى الأرض في حركة دراماتيكية تترجم قراره بالارتقاء فوق المستوى الأرضي؛ فهو سيحمل روحه على راحته، ثم يهبط بها إلى الأرض، وهي المستقر الأخير وإن كانت الروح ستصعد ثانية إلى أعلى فهو من أعلى إلى أسفل ويالتبعية إلى أعلى بطبيعة الحال (في السماء) فلو أعطينا الأعلى رقم 1 و الأسفل

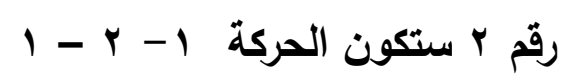

وحين استخدم الطباق مرة ثانية نشعر وكانه يؤكد تلك الحركة الدراماتيكية في الصعود واللهبوط، وذللك باستخدام الطباق في كلمتي (السماء الثرى)، وهو يتناسب مع الطباق الأول الأي استفتح به الأبيات ما بين العلو والانخفاض فهو بانخفاضه إلى مستوى الأرض بصورة شهيل يعني

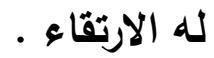




\section{قصيلة (الثشهيا) لعبد الرحيم محمود قراءة أسلوبية}

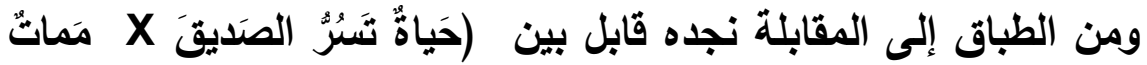

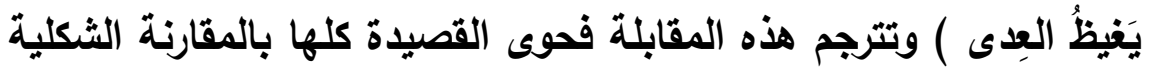
بين موقفين موقف القرار الحاسم والخطير الذي هو في ذاته أخطر قرار في حياته كلها والقرار الذي يرفضه قلبه وعقله، وهي شكلية في مستواها البسيط وهي (مساواة) في معناها العميق .

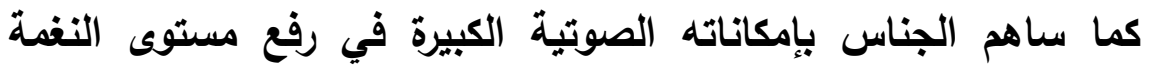
التصاعدية المسايرة للحال النفسية والذي كان بين الكلمات : (روحي وراحتي) (المنايا - المنى) (العيش - عثت) وقد جاعت عفو الخاطر تلقائية بسيطة أدت دورها الموسيقي في تنامي الإيقاع الداخلي وإكسابه

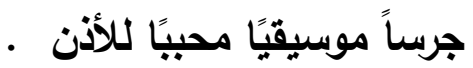
أما حسن التقسيم وهو الذي ينتج عنه نغم تماثلي متماوج يساعد المتلقي

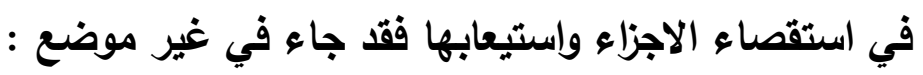

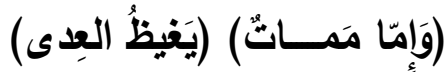

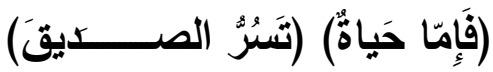

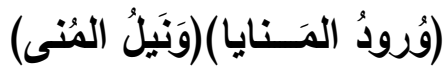
(وَتَفسُ الثُرَيفِ) (لَها غايَتَـانِ)

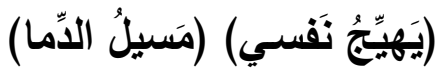

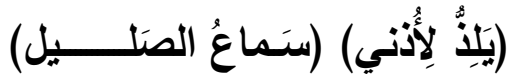

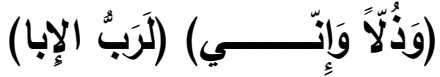

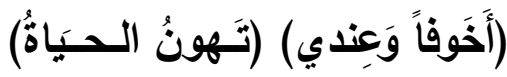

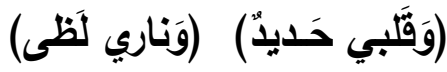

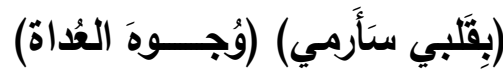

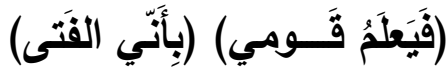

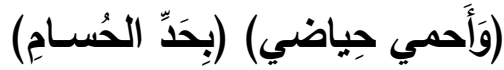

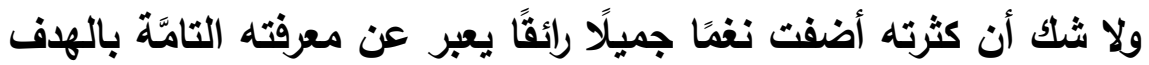
الذي حارب من أجله، فالتقسيم إلى مقاطع موسيقية بهذا الثكل بعكس إنسان

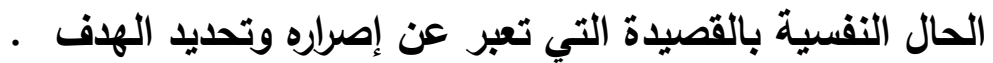


والقافية هاهنا تسير في انزياحات عروضية واضحة عما عُهِ في القالب الثعري الذي اتخذه شاعرنا لقصيدته فالقافية في أول بيتين موصولة، أنيا،

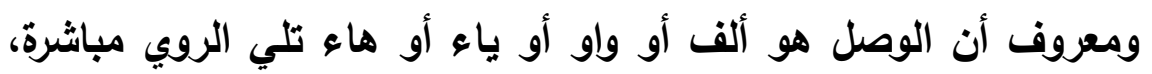
وكان الروي هو الدال الموصولة بالألف، والدال من الحروف التي كثر التر التراء

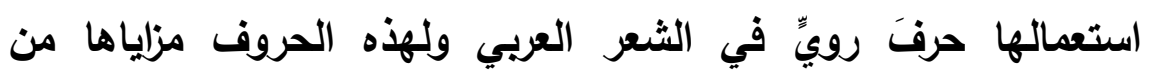

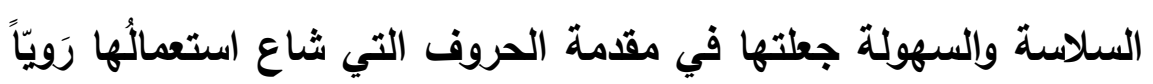

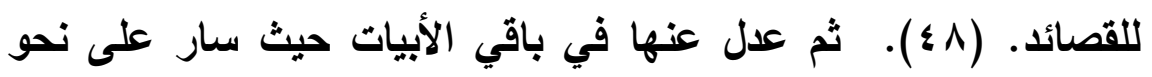

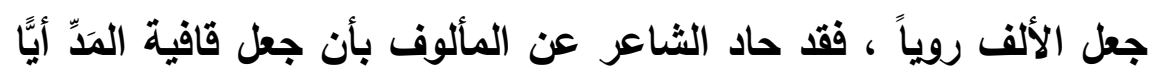

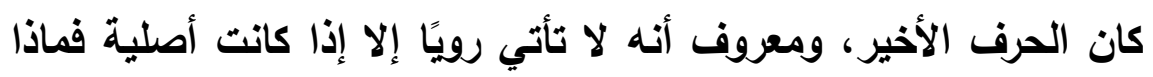

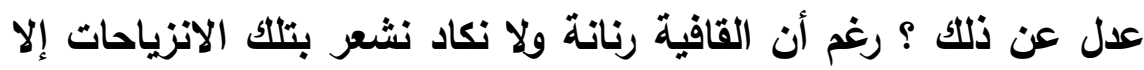

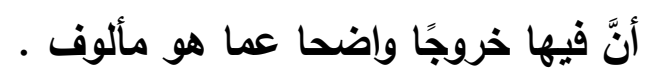
والألف إذا كانت روياً يثترط فيها أن تكون أصلية، ولكنه في انزياح

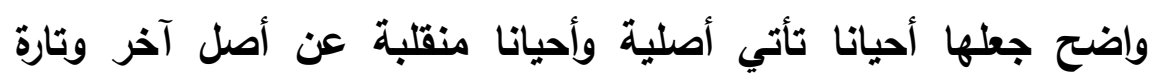

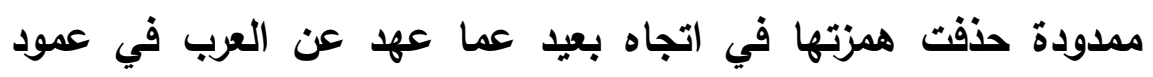
شعرهم القديم ! وأضم صوتي لصوت محمود حامد بأن الثاعر لديه قدرة جيدة في صياغة

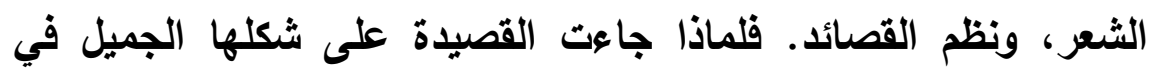

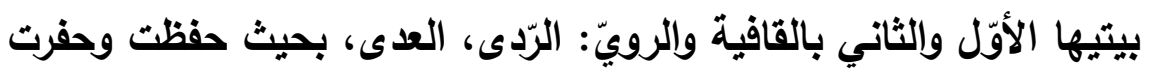

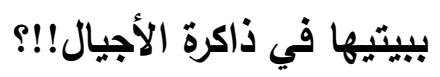
لماذا لم يكمل الثاعر قصيدته على القافية والرويّ كما ورد في البيتين (1) و (Y) كما فعل الثابي في قصيدته: إذا الثُبُ يوماً أرادَ العياة

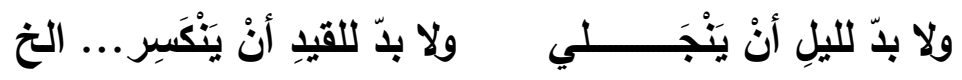


لو فعل عبد الرحيم محمود ذلك لخلات قصيدته كلها كقصيدة الثابي، أو على الأقلّ لو جلها ثُلاثيات، أو رياعيات، أو ثنائيات، كما في البلاية،

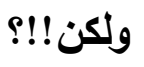

ومع ذلك فإنّ القصيدة ولو ببيتها الاثثين، فإنها أيضاً خلات في: ذاكرة

عابل..ودليل قدرة الثاعر عبد الرحيم محمود على صياغة القصائد الطويلة

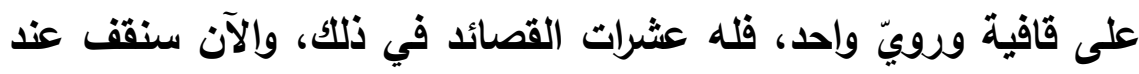
مقطع من قصيدته التي نظمها في البصرة، عندما كان مديراً لمدرستها فئها

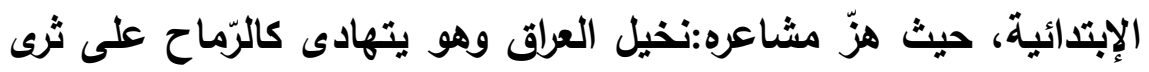
جزء من وطن العروية... فنكّره النّخيل ببرتقال فلسطين، وتينها وزيتونها،

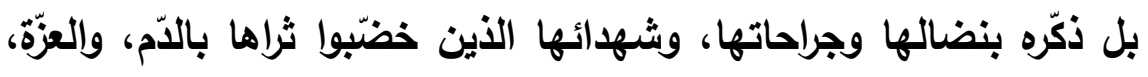

$$
\text { والكبرياء: }
$$

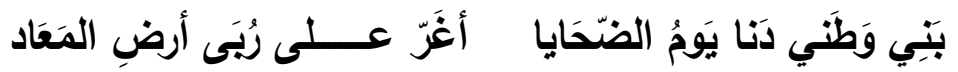

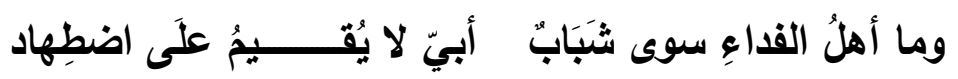

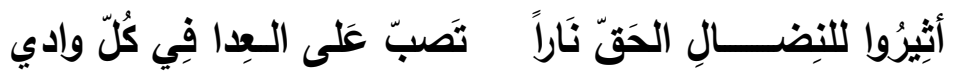

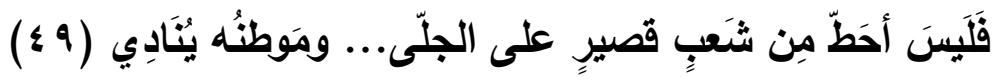
المستوى التركيبي تمتاز القصيدة باللهجة خطابية، ومن شأن الخطيب أن يلوّّن في الألفاظ،

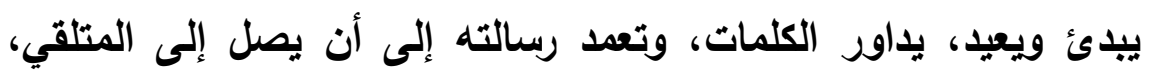

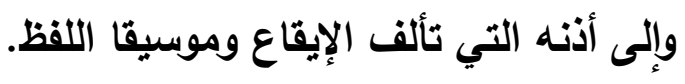

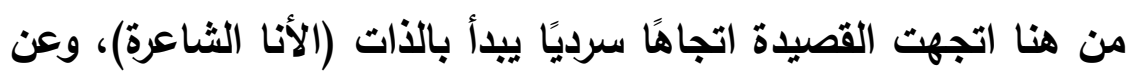

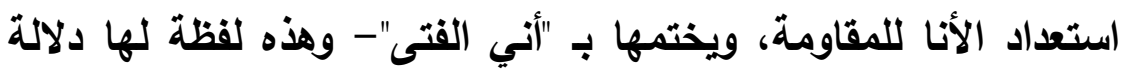
جامعة من البطولة والمروءة. 
والملاحظ أن كلمات القصيدة بسيطة جدا تثبه لغة الصحف التي تتجه نحو الفصحى الميسرة فلا تعقيد للفظ ولا إغراب للمعنى بلهجة خطابية مباشرة، ولعلَّ هذا من أكبر أسباب شيوعها وإنتشارها بين العامة والخاصة، ويبدو أيضًا أنَّ الثاعر تعمَّد ذلك؛ كي تصل إلى جميع الناس؛ فالثهيذ شهيذ الأمة كلها وليس مختصًا بإقليم مكاني معين، فهو شهيذ كل بيث عربي مسلم، لألك لابد أن تلخل كلمته لبيث العامة وييت الخاصة.

" تتبدى لغة الأت في الضمائر التي جاءت على النحو الآتي :

\begin{tabular}{|c|c|}
\hline عدد مرات وروده & الضمير \\
\hline 16 & ياء المتكلم \\
\hline 8 & هاء الغيبة \\
\hline 2 & كاف الخطاب \\
\hline 2 & تاء الفاعل \\
\hline
\end{tabular}

" ثُ" الضمير المستتر أو المنفصل "أنا"، "ياء "المتكلم، وهي تثردد وتثيع في القصيدة كلها، لا يقطعها إلا الحديث عن ضمير الغائب (هو)، وذلك بلدًاً من البيت التاسع الأي يبدأ بـ "وجسم تجدل...."، فهنا يصف الثاعر شهيدًا بامهه ورائحته، ويكونه عرضة أو طعمة للطير والوحش. وهذا الوصف إما أن يكون الفعل فيه حقيقة، أو فيه مبالغة، وإما أن يكون

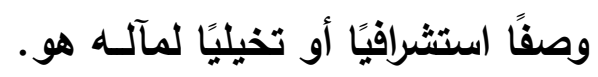

تنعكس دلالة السرد والخطاب معًا أولاً في استخدام حرف العطف (الواو) في أكثر من عشرين مرة، حيث نجد فيها النفس القصصي التعبيري المباشر، وكأنها حكاية تسرد على المتلقين. 


\begin{tabular}{|c|c|}
\hline لرحيم محمود قراعة أسلوبية & أما الأقعال : \\
\hline عدد مرات وروده & الأفُعال \\
\hline 18 & المضارعة \\
\hline 11 & الماضية \\
\hline
\end{tabular}

فنجد دلالة السرد والخطاب كذلك في أفعال المضارعة أو ما هو في معناها، فليست الديمومة هنا هي الفعالة بقدر ما نجد فيها معنى الحاضر والمستقبل من خلال الإيقاع والوتيرة، بل إنَّ الأفعال الماضية (قلت)، (كسا)، (أثقل) ونحوها تأتي بمعني الاستقبال والروئة من خلال الآتي، كما

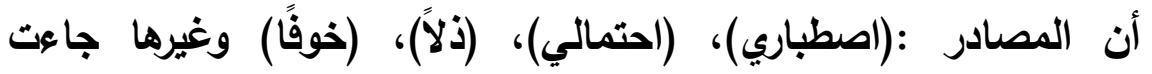
تحاشيًا من استخدام الفعل الأي يجافي طبعه، فهو يستبعد (أخاف) أو (أذل) من قبيل الأنفة، فجعل المعنى في اسم المعنى الأي هو المصدر، ليكون الحدث أخف وطئًا. الثاعر في خطابه أو سرده يكرر بعض الكلمات ترسيخًا وأداعًا لنبرة موسيقية، نحو (لعمرك)، فقد كرها مرتين للتنبيه، ويذا ينحو نحو لهجة الناس في حديثهم وتأكيدهم، ولا يريد بذلك القسم المجرد، فهو ليس

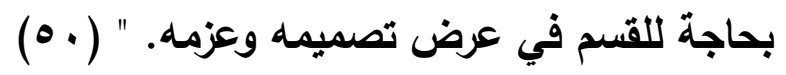
ويكرر السين قبل فعل المضارعة في الإجابة عن الترقب، حتى لا يختمر الثك ، فالمتلقي ينتظر ماذا سيقول، وماذا سيفعل. سأحمل روحي على الاجله راحتي، وفي الختام" بقلبي سأرمي وجوه العداة "والسين كما نعرفها للتنفيس - أي لسرعة تحقق الفعل، أو كما ذكر الزمخشري أنها للوعد

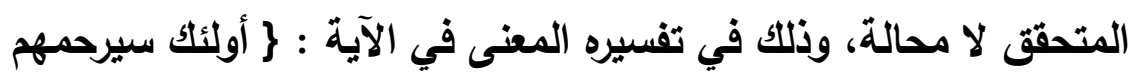
الله|(التوية الآية :19)، وفي قوله في نفس السورة" سياخلهم "(آية: 
أما تكرار (إمَّا) التفصيلية فيأتي في مقابلة بلاغية وتطبيقية تضع الكفتين في الميزان لتكون الخيرة لإحداهما: فإما حياة تسر الصديق وإما ممات يغيظ العدى وتكرار (قلب) له متابعة وتحصيل للنتيجة:

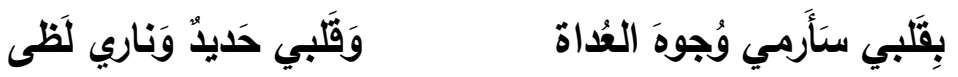

كما يكرر لفظة ترتبط بقيم العربي الأصيلة، وحتى في لغتنا الدارجة (الشريف)، ففي الأولى تكون اللفظة عامة" ونفس الثريف لها لهاتئ غايتان"....، بينما في الثانية ترتبط باستشهاد الرجال، فهذا الموت

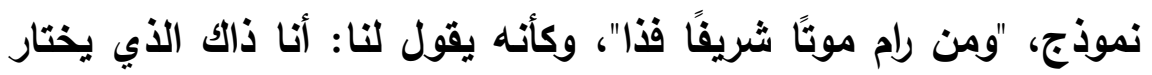
طريق الموت، أنا ذاك الشريف؛ ويتكرر لفظ الاستدراك (لكن)، ففي المرة الأولى يقول " ولكن أغذ إليه الخطى"، وتأتي الاستدراكية بعد قوله: " إني أرى مصرعي"، ، ففي ذلك

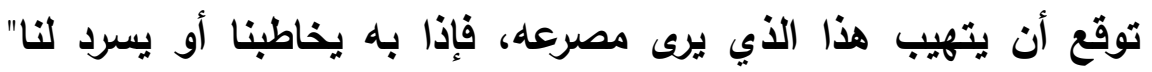
ولكن...."، ومثل ذلك في قوله عن الشهيد الذي يصفه واقمًا أو استشرافًا: وعفرَ مِنهُ بَهِي الجَبِين"، فالثَاعر يخشى أن نظن أن صورته غير مرضية أو هي مشوهة، فإذا به يلحق (لكن)ليدل على أن هذا العفار يزيد بهاء الشهيد. وعلى الإجمال فهو يخاطب ويسرد وكأنه يتخيل جمهورًا ينصتون

كما نلاحظ ترتيب الجمل بما يضفي هذا الإيقاع، المتناغم مع المستمع، ويما فيه من تكرار اللفظ: فكيف اصطباري لكيا.... وكيف احتمالي لسوم......

$$
\text { أخوفًا وعندي...... أذلاً وإني............ }
$$

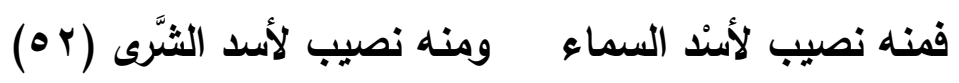




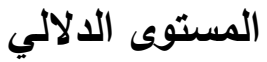
لا نكاد نرى الأساليب الإنثائية إلا عند نهاية القصيدة؛ فقد سارت على الإئ

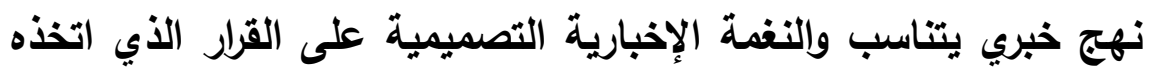

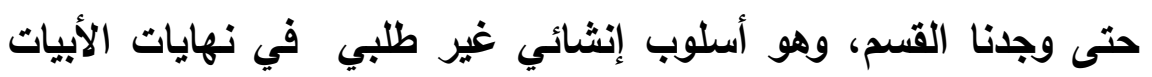

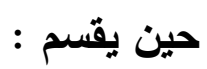

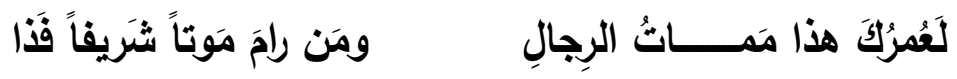

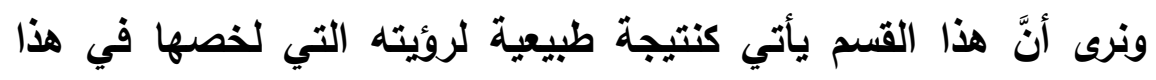
البيت الأي يحمل سبب قرار الثهادة فلزم التأكيد باستخدام (لعمرك) دريعًا

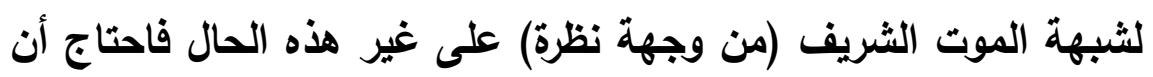
يؤكدها بهذا القسم الذي قصر فيه موت الرجال الحقيقيين الذي يستحقون

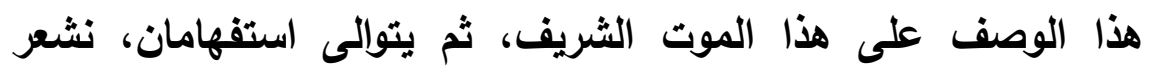

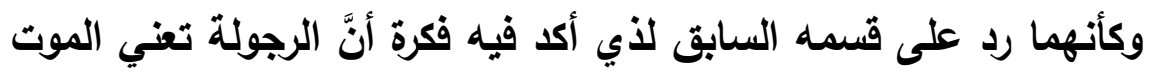

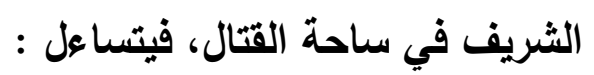

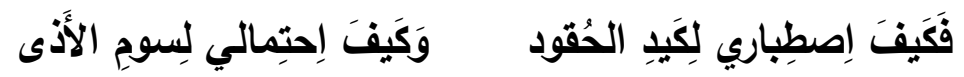
استفهام استنكاري لمن يجهل السبب الذي جعله يتحمل كيد الحقود وما عاناه من أذى، ونشعر بطلو ثورة الغضب في هذا البيت من خلال استخدام هذا الاستفهام الاستنكاري الذي شفعه بهذا الاستفهام :

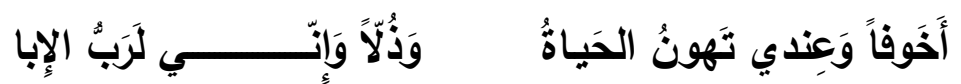
انطلق من بيان سبب اقتحام الموت وهو الذي هوَّن عليه كيا الحقود

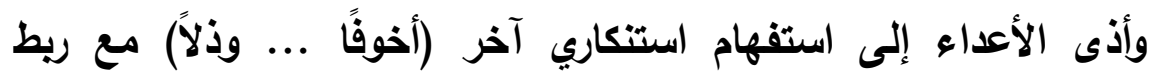

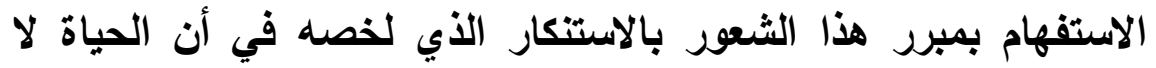

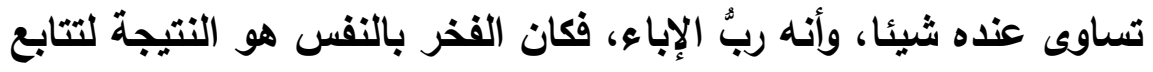
استفهامين استنكاريين لريط الأسباب بمسبياتها، وكأن هذين الاستفهامين 
قـ كثفا عن حقيقة الثاعر التي كنا نجهلها وقث أوشت بها عاطقته الجياشة التي أبرزت الاستفهامين وكثفتا سر شخصيته التي تستحق

\begin{tabular}{|c|c|}
\hline عدد مرات ورودها & الصورة \\
\hline 4 & التشبيه \\
\hline 6 & الاستعارة \\
\hline 7 & الكناية \\
\hline 1 & المجاز المرسل \\
\hline
\end{tabular}

فإنتا نجد توظيفً جيدًا للتصوير القني بأنواعه الأربعة تثبيهًا واستعارةً

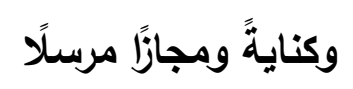

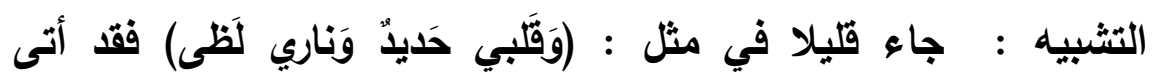
بتثبيهين بليخين على صورة المبتدأ والخبر فيوحي بما تكسبه الجملة

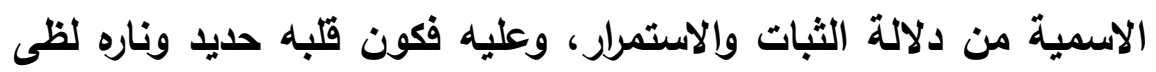
هذا ثبات للحال واستمرارها، فقد شبه قبله بالحديد على غرار ما فعل قبله عنترة، وما قاله المتنبي فهو لا يرى نفسه بأقل منهما وإنْ كان أفضل في

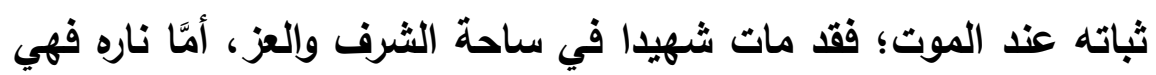
لظى وهي اسم من أسماء جهن (به) فهو يتبع سياسة الحديا والنار التي عجزت عنها الثعوب العربية مع المستعمر تلك التي كانت تمارس عليهم، جعلها الشاعر أيقونته وسياسته في التعامل مع الأعداء فلا خوف

ولا ضعف .

ومن الاستعارة :

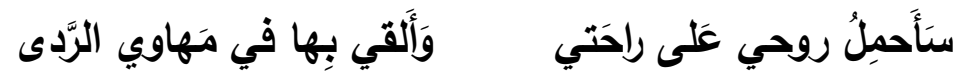




\section{قصيدة (الثشهيا) لعبد الرحيم محمود قراءة أسلوبية}

استعارة مكنية جسَّد فيها الروح بكيان يحمل ثم يلقى به .

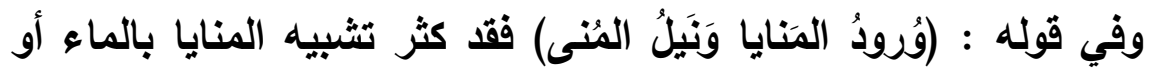
كأس الماء أو بنبع الماء في الثعر العربي القديم، كما سبق وأن وصفها

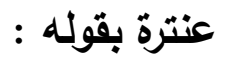

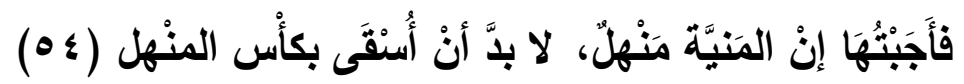

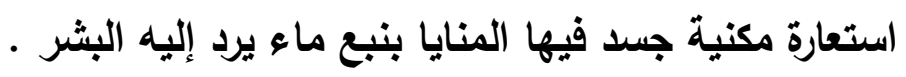
وكنلك في تجسيد الأرض بصورة كساء يكسو الأرض بالأرجوان من خلال

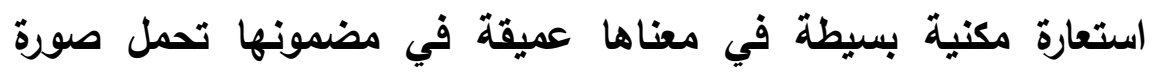

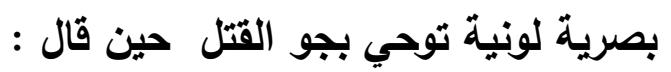

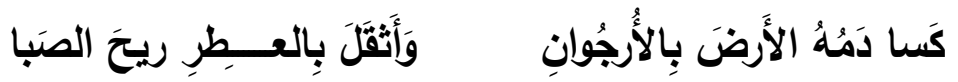
كما ركَّب عليها استعارتين (أنقل بالعطر ريح الصبا) في صورة فنية

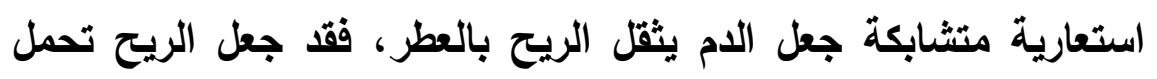
العطر وجعل العطر مثقالاً له وزن .

ثم يعود مرشحًا صورة الدم مشخصًا له بإنسان يعفّر الجبين بلون الدماء بعفار ليس كما عُهِه، إنما هو زينة تزيد الجبين بهاء :

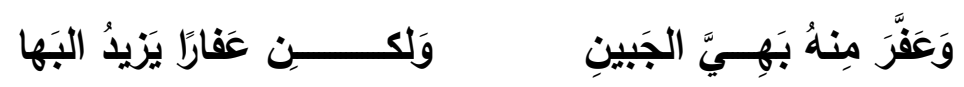
وقد جسد القلب يما يرمى ويجرح وجوه العداة حيث صوره لنا بصورة قنبلة ترمى في وجه أعدائه فيقتلهم بذلك القلب الذي يرفض الثاعر وجدان أن تكون

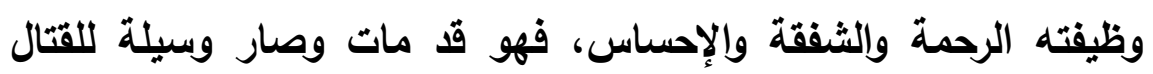

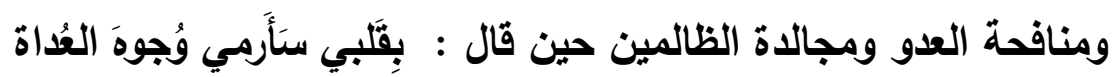
ومن الكناية :

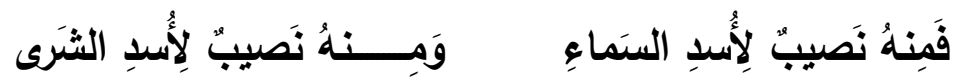


فقد كنى عن صفتي الارتقاء والموت بكنايتين هما الصعود الملائكة بالروح إلى أبراج السماء العليا وكذلك أن يصبح طعاما لوحوش الأرض، وإذا كانت الكناية تستمد جمالها من كونها تأتي بالمعنى مصحويًا بالاليل فقد أتى بمعنى ارتقاء جسده الثريف إلى أعلى بكنايته، وإلاليل عليها أن أسد السماء وهي بروجها ويقصد الملكوت الأعلى لها نصيب منه فمستقرة بين الأسود والأسد رمز القوة والثجاعة عند العرب فاختار من بروج السماء (الأسد)، وحتى الأسود لها نصيب من جسده، فالأرض لم تستطع أن تودي به؛ فمنزلته أعلى من أن يدفن في باطن الأرض فتحول إلى الى هن نصيب الأسد ليستقر في بطن الأسود التي لا يقل عنها شجاعة، فحتى لهن لهن في موته لا يدفن في باطن الأرض إنما يدفن في باطن أشد وجوش

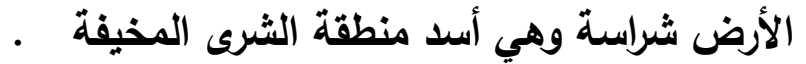

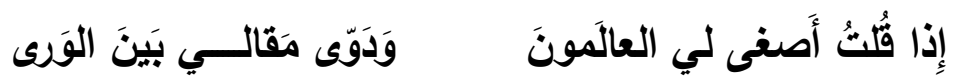
وهي كناية عن قوة التأثير وأن صوته مسموع أمام العالم، وما دام صوته لهاته مسموعًا فقد صارت لله هيبة وله كلمة وله صولته فيُسمع ويُهاب، عمَّث من قوة الكناية استخدام اللفظ الأقوى في الصوث وهو الدوي الذي هو في

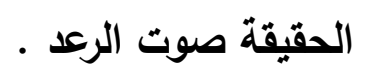

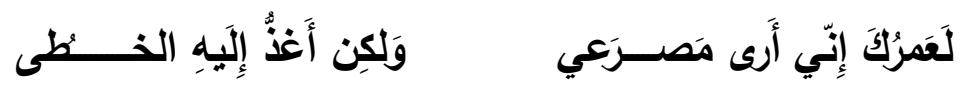
كناية عن الشجاعة وعدم الخوف، فهو يرى مقتله ويدلاً من أن يجزع نجده يسير إليه بخطى حثيثة، فمن يملك تلك الشجاعة منقطعة النظير إلا شاعرنا فهو يكتفي بعدم الخوف بل يسير إلى حتفه راضيا مطمئنًا . وكذلك :

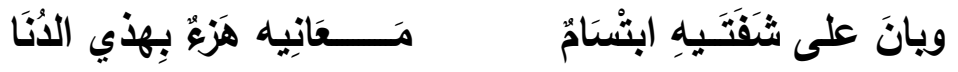


قصيدة (الشهيخ) لعبد الرحيم محمود قراعة أسلوبية

كناية عن الثجاعة الزائدة التي جعلته يسخر من الموت لإدراكه قيمة

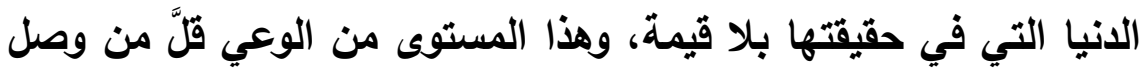
إليه فالناس يتقاتلون على لا شيء :

النفس تبكي على الانيا وقا علمت أن السلامة فيها ترك ما فيها

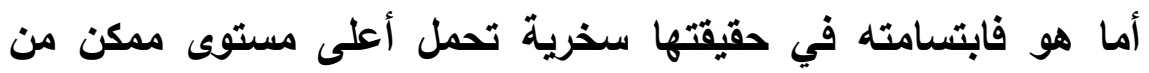
الوعي وهو إدراك حقيقة الدنيا .

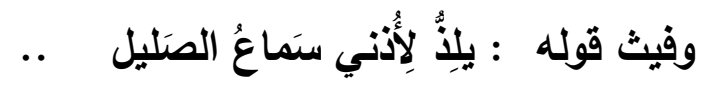
كناية عن حب القتال والتثوق إلى أصوات آلاته، ولكنتا لا نستخدم

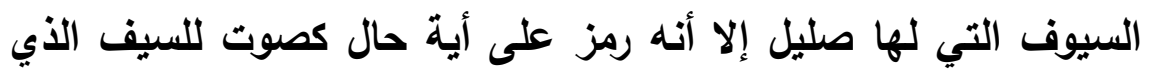
هو في الأصل رمز للقوة واللسيطرة .

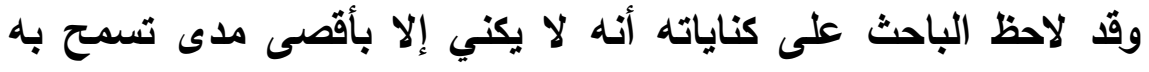

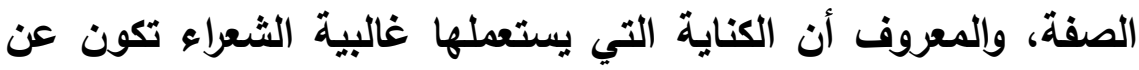

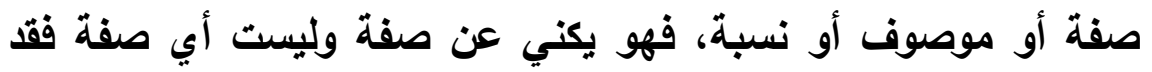

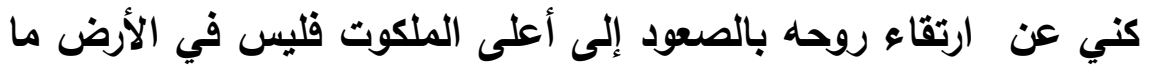

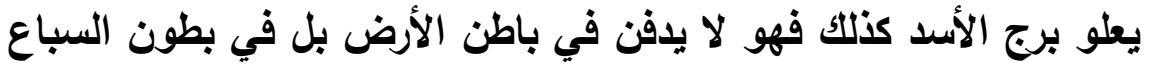

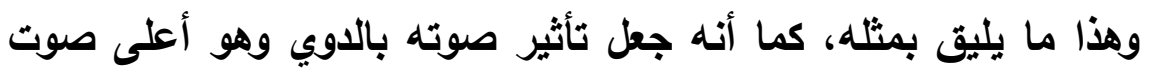
وهو صوت الرعد الذي يثير الخوف في النفوس. وقد وصل بكنايته إلى أعلى مستوى من الوعي بأن أدرك حقيقة الانيا، وكنلك حين كنى عن شجاعته واستهانته بالموت لم يكتف فقط بروئية

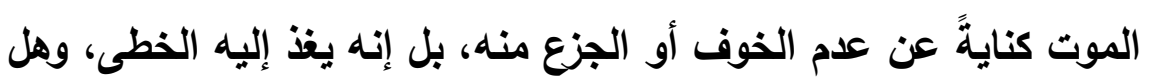

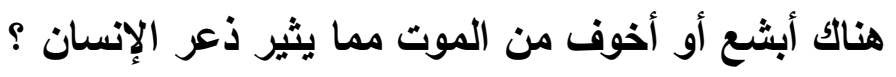
ومن المجاز المرسل في قصيدتنا : 
وإما ممات يغيظ العدى : هناك من يرى أن الموت هنا مجاز مرسل علاقته (اعتبار ما سيكون) أو (مسبيية) فيقول :

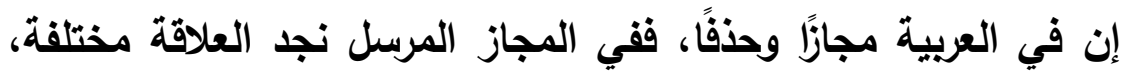

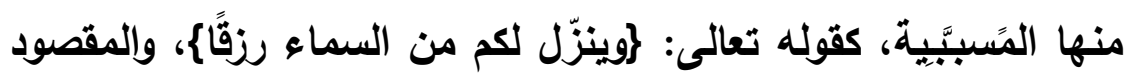
المطر الأي هو سبب للززق، ومنها "اعتبار ما يكون" وهو لاى البلاغيين "الاستعداد"، كما في قوله تعالى: \}إنكك إن تذرهم يضلوا عبادك ولا يلدوا إلا فاجرًا كفاراج، فالمقصود بالطبع أن المولود في التوقع سيؤول إلى الكفر والفجور. وفي كلا التصورين يمكنتا أن نفهم أن الموت هو المنتج عن المعركة، أو أن الموت هو ما ستؤدي إليه حرب البطل، وعلاقة الاستعداد لاى البلاغيين تثي بذلك معنى ودلالة (ه0) وأضم صوتي لصوت من يرى ذلك . 


\section{قصيدة (الثهيا) لعب الرحيم محمود قراعة أسلوبية}

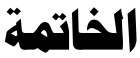

خرجت الاراسة بمجموعة من النتائج رصدتها من خلال الملاحظات الآتية: الألفاظ بسيطة لا تعقيا فيها، ميسَّرة، لم يَغُص في أعماق المعاجم كي لفي ينحت من صخر ليأتي بالغريب منها، إنما جاعت عفو الخاطر بسيطة

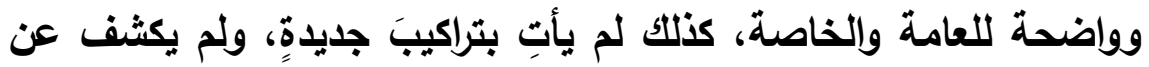
علاقات جليدة بين الألفاظ من خلال ابتكار أساليب جديدة بل على العكس جاعت في مجملها بسيطة . البحر الثعري جاء مسايرًا للقدماء، لم نر فيه تطولًا أو انزياحات كثيرة غير بعض الزحافات البسيطة التي استُهِكِت من قبلُ خلال استعمال بحر المتقارب واختياره كان موفقًا للحال النفسية للشاعر الثائرة . القافية حملت كثيرًا من الانزياحات التي خرجت عن المألوف، فقد بدأها بروي الدال الموصول بالألف، ثم عدل إلى أن جعل الألف نفسها رويًا

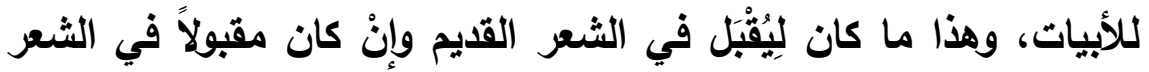

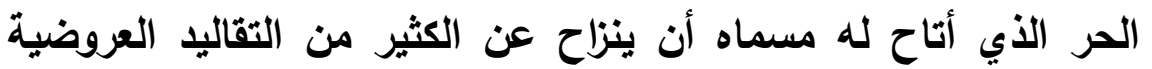
الموروثة رغم أن شاعرنا انتهج نهج القصيدة العمودية. جاءت محسناته البديعية عفو الخاطر لا اجتلاب فيها ولا إقحام، بل سايرت الأبيات بتلقائية جميلة ساهمت في رفع نغمة الموسيقى الداخلية

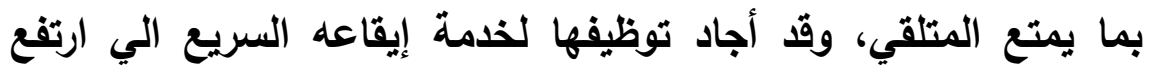
أحيانا وإنذض أحيانا تبعا للحال النفسية الداخلية . جاءت صوره بصفة عامة تقليدية بسيطة لا نجد فيها ابتكارًا ولا توليدًا للمعاني والأخيلة ولا تراكيب جليدة وإن كانت تحمل الفخامة وطلب العلا، 
فصوره رغم كلاسيكيتها إلا أنها كانت تنشد الوصول بالخيالي الشعرى إلى أقصى غاياته كما رأينا مع كناياته . يكثر شاعرنا من التناص مع القرآن الكريم، وكذلك مع أشعار المتببي

\begin{tabular}{|c|c|c|}
\hline & \multicolumn{2}{|c|}{ وعنترة على النحو الآتي : } \\
\hline \multicolumn{2}{|r|}{ عدد مرات وروده } & التناص \\
\hline \multicolumn{2}{|r|}{1} & من القرآن الكريم \\
\hline \multicolumn{2}{|r|}{2} & من الأقوال المأثورة \\
\hline \multicolumn{2}{|c|}{9 مرات على النحو الآتي: } & \multirow[t]{6}{*}{ من أثعار العرب } \\
\hline 1 & الإمام علي & \\
\hline 2 & عنترة & \\
\hline 4 & المتتبي & \\
\hline 1 & ابو تمام & \\
\hline 1 & ابراهيم طوقان & \\
\hline
\end{tabular}

ومن هنا يثور السؤال : فمن خلال ما سبق نلحظ غلبة التقليدية على هذه القصيدة ورغم ذلك فقد كتب لها الثيوع والانتشار، وتيسرت لها عوامل الخلود، فمن أين جاعتها تلك المكانة، رغم أننا في حقيقة الأمر لو قيَّمناها فنيًا فسنجد أنَّ هناك ما كتب من قصائد في مجالها ما يفوقها روعةً في كثيرمن النواحي القنية، ومع ذلك فهي تقف شامخةً بين عيون القصائد الحماسية فما السر في ذلك ؟ أرى أن ما كتب لها الخلود والذيوع صدق عاطقتها الجياشة التي نبعت من نفس الشاعر المقاتل، الذي عايش الحرب بنفسه، ولم يعش في برج عاجي يكتب وينسج من خياله بطولات وهمية ، فهي قصيدة من قلب 


\section{قصيدة (الثهيل) لعبا الرحيم محمود قراعة أسلوبية}

الحدث وليدة المعمعة صدقت فيها مشاعره، ونرى فيها صدق التجرية الشعرية، فالصدق هو الحدود الأربعة لجغرافية هذه القصيدة التي

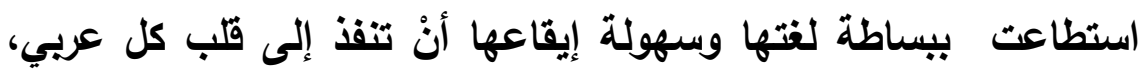
كما أن كون الثاعر شهيدا فقد أضفى على القصيدة مصداقية أكبر لأن النهاعل شاعرنا صدق قوله عمله . 

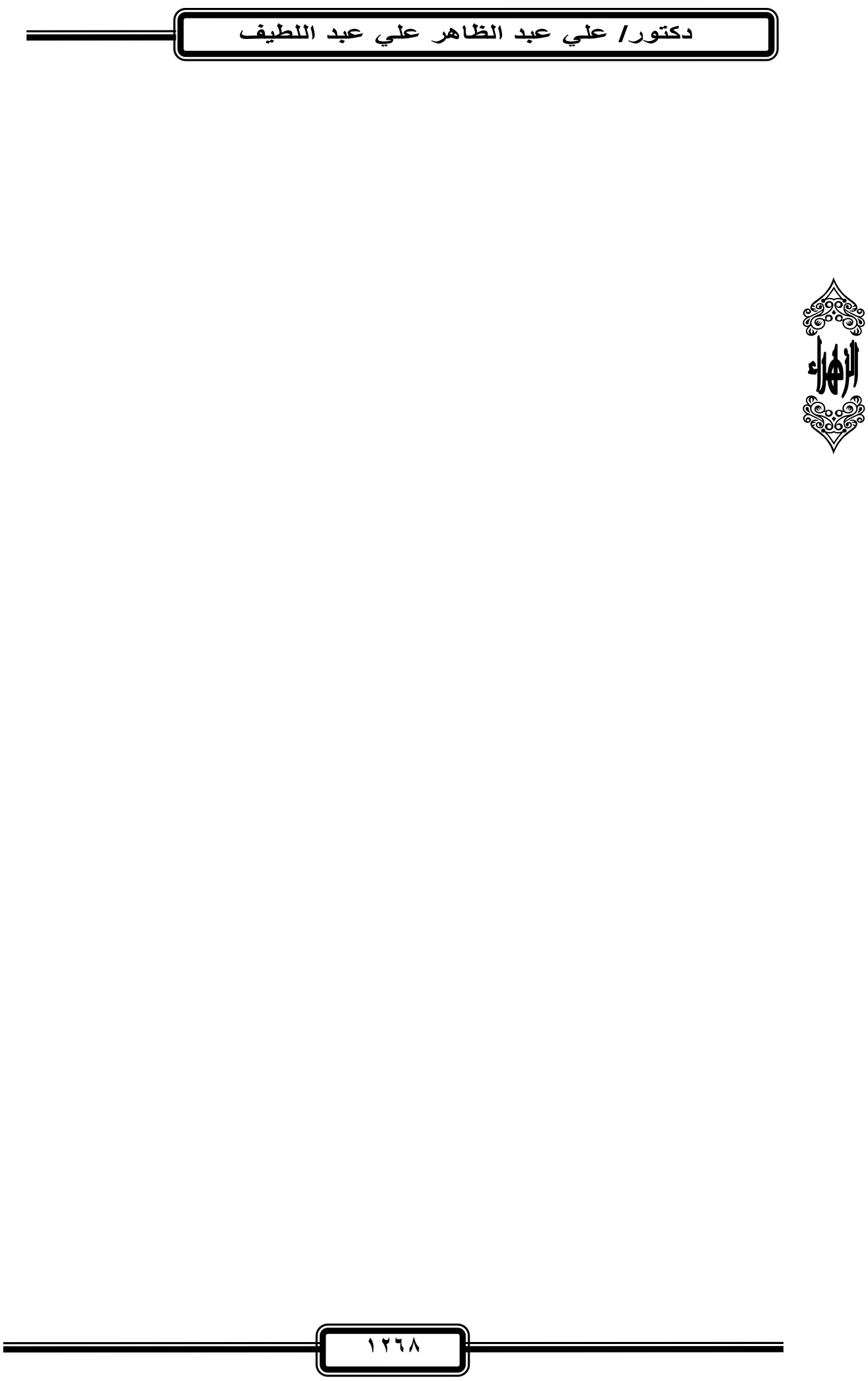


\section{قصيدة (الثهيا) لعبد الرحيم محمود قراعة أسلوبية}

\section{هوا هش الدراسة - - ماسة}

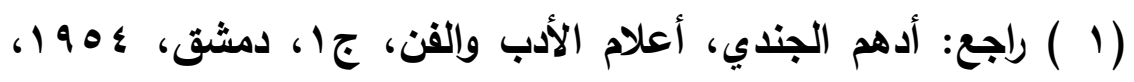
ص •^ז؟ ديوان عبد الرحيم محمود، اتحاد الكتاب والصحفيين الفلسطينيين، بيروت، ؛و 19، مقدمة الديوان بقلم كامل السوافيري؛ روحي على راحتي، ديوان عبد الرحيم محمود، حققه وقدم له حنا أبو حنا،

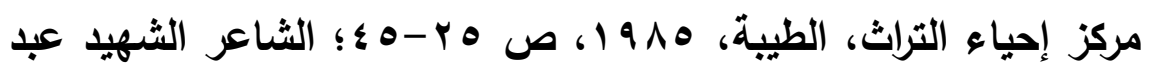
الرحيم محمود، مكتبة بلاية نابلس، نابلس، ه \q 1؛ إبراهيم عبد الستار،

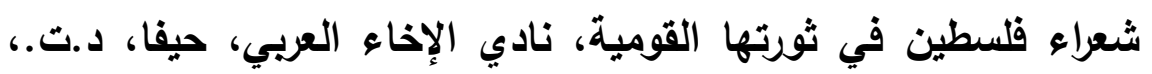

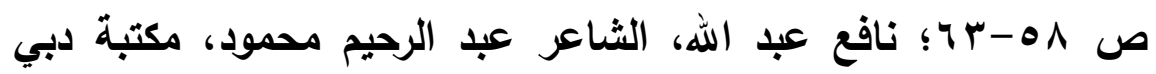

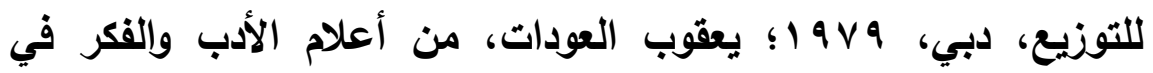

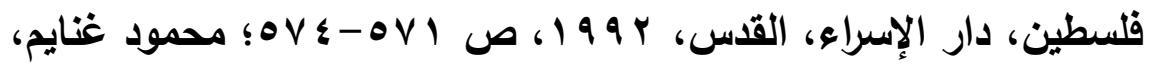

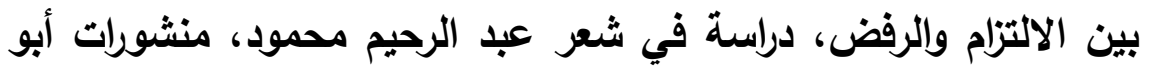

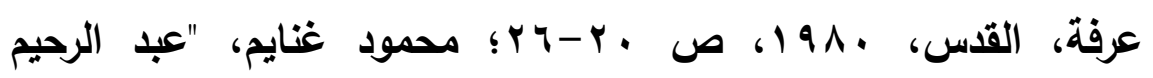

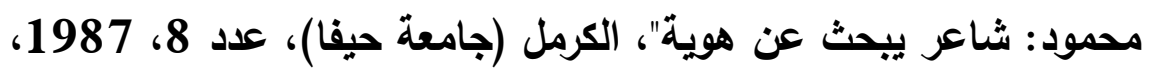

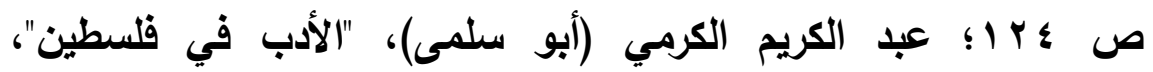
محاضرات الموسم الثقافي، جه، وزارة الثقافة والإششاد القومي السورية، لكئ،

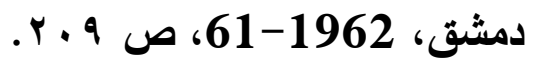

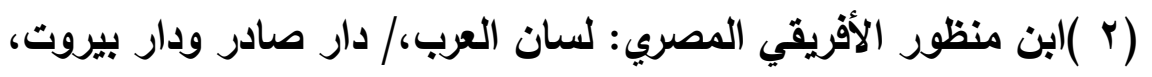

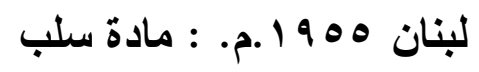
(ץ)(بن قتيبة :الثعر والثعراء ، تد./ أحمد محمد شاكر ، دار المعارف،

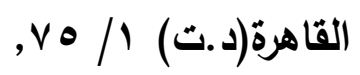


(ع) (بن خلاون : مقدمة ابن خلاون ، تح. حجر عاصي، منشورات دار ومكتبة الهلال، بيروت، لبنان

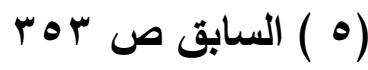
(†)أحمد حسن الزيات: دفاع عن البلاغة، عالم الكتب ط ،بابيروت، لبنان V 1978 أحمد الثايب: الأسلوب ، مكتبة النهضة المصرية طج، القاهرة \& $ะ$ ص) 979 (^) عبد السلام المسدّي : النقد والحداثة، دار الطليعة للنشر طا، بيروت $.0 \leqslant$ ص. $191 \mathrm{r}$ (9) بييرجيرو: الأسلوب والأسلويية، ترجمة /د. منذر عياشي، مركز الإخاء القومي، بيروت، د. ت ت ص ، 7.

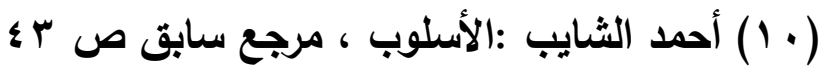

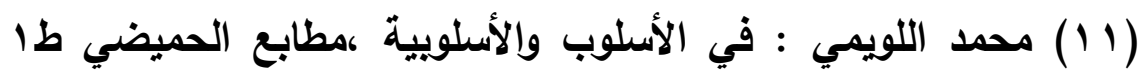
(1) (Y Y I ) يوسف أبو العدوس: الأسلويية الروية والتطبيق ، دار المسيرة طا، TV (IT) شكري محمد عياد : مبادئ علم الأسلوب العربي، مطبعة انترناشيونال بريس، طا،

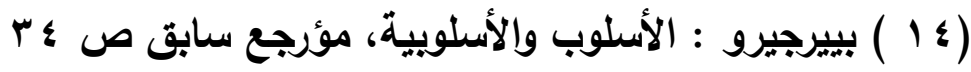
(10) فائق مصطف ي ود. عبد الرضا علي: في النقد الأدبي الحديث،

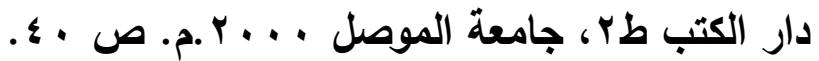

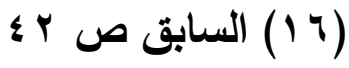


(IV) يرى جبرا إبراهيم جبرا أن الثاعر قال القصيدة في رثاء صديق له له

في الثورة الفلسطينية، فجاءت رثاء لنفسه أيضًا إذ تنبأ فيها بنهايته . انظر :إبراهيم جبرا :الرحلة الثامنة ببيروت، 9211 ، ص 91 ، ويذهب كذلك سليمان جبران من خلال دراسة للثاعر أن القصيدة هي في رثاء صديق له من شهاء الثورة الفلسطينية انظر كتاب جبران، سليمان :نظرة جليدة على الثعر الفلسطيني في عهل الانتاب /حيفا :سلسلة منشورات الكرمل، 19001 ( 9015

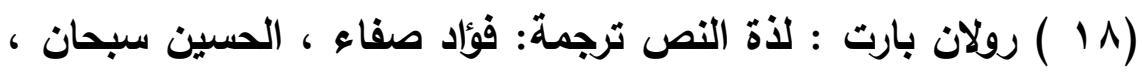

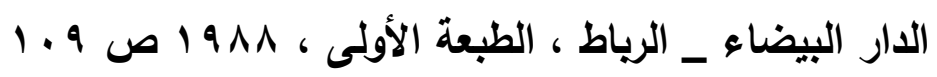

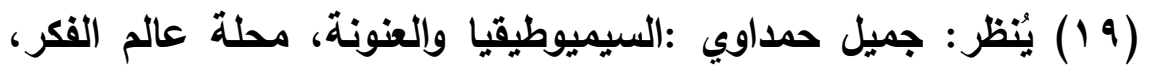

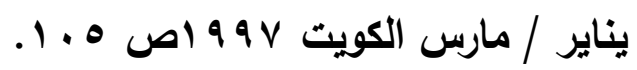

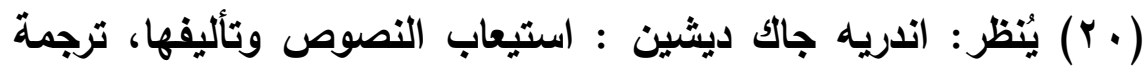

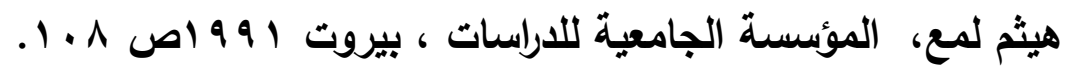
(Y) رافع يحيى : الإشراقي والأرضي في شعر البياتي، بيروت، لبنان ص IV (Y (Y) عبدالله الغذّمي: ثقافة الأسئلة مقالات في النقا والنظرية ، دار

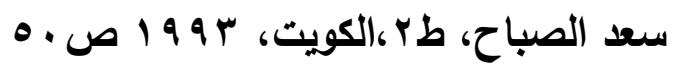

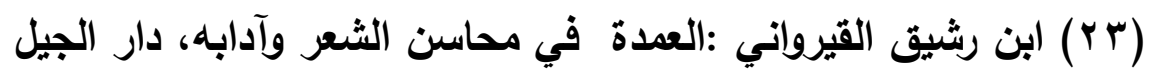

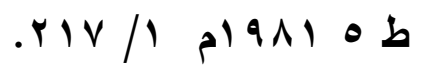

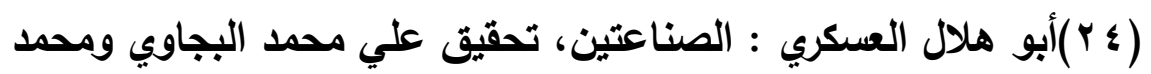

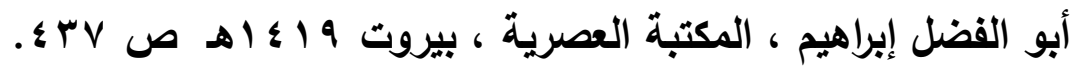

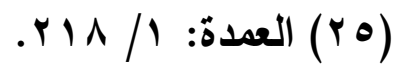

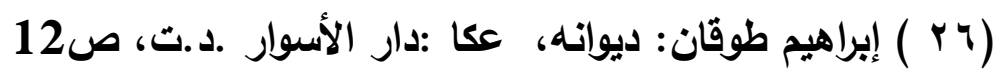


(YV) انظر : فاروق مواسي : قراءة جديدة لقصيدة" الثهيد "في معنى

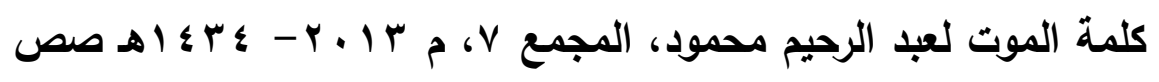

$$
(r r \cdot-r \cdot q)
$$

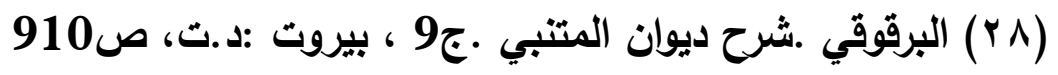

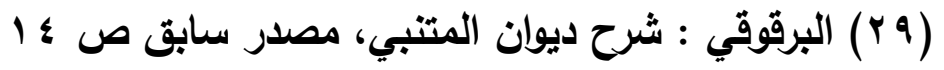

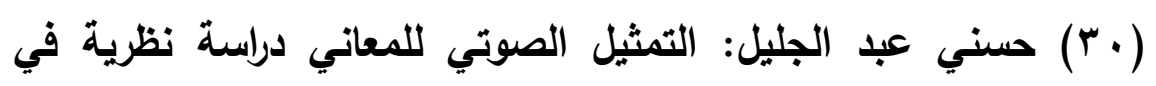

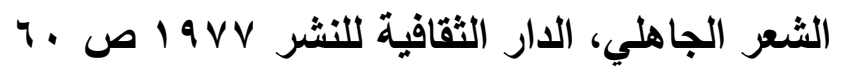

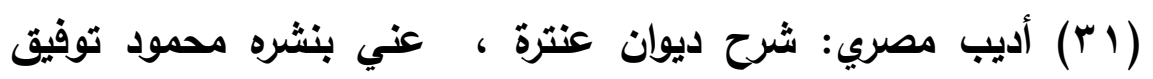

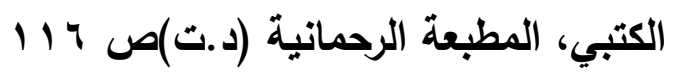

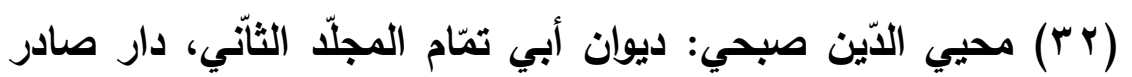
بيروت لبنان 1997 ص304

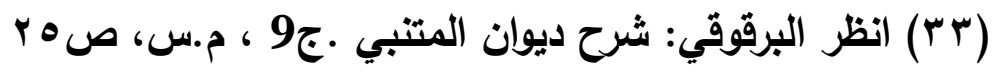

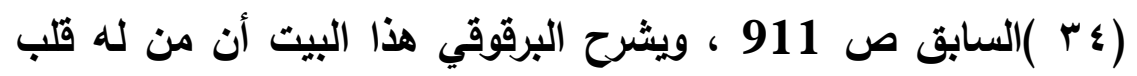

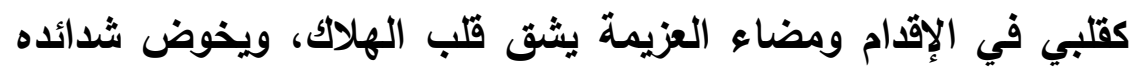

$$
\begin{aligned}
& \text { حتى يصل إلى العز }
\end{aligned}
$$

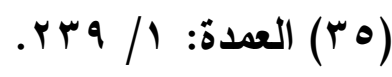

( آץ) ينظر : يحيى بن حمزة العلوي :الطراز لأسرار البلاغة وعلوم حقائق

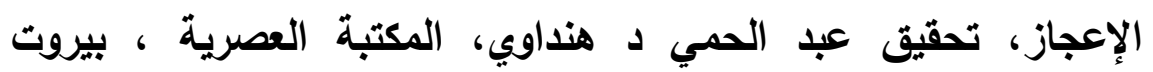
. (rv) علي بن أبي طالب رضي الله عنه ديوانه ، تحقيق : عبد الرحمن المصطاوي، طبعة : دار المعرفة بيروت - لبنان ، ص هو 9

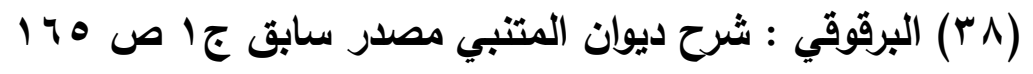




\section{قصيلة (الثهيا) لعبد الرحيم محمود قراوة أسلوبية}

(rq) توفيق الزيدي : أثر اللسانيات في النقد العربي الحديث طا. الدار

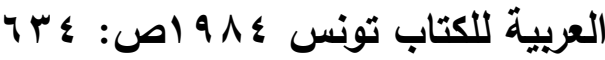

( • • ) ريتثاردز، آي: مبادئ النقد الأدبي، ترجمة محمد بدوي، المؤسسة

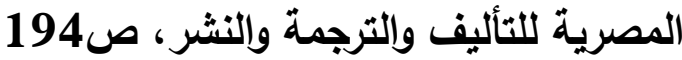
(1) ينظر: عز الدين إسماعيل :نظرية الأنواع الأدبية، ترجمة حسن

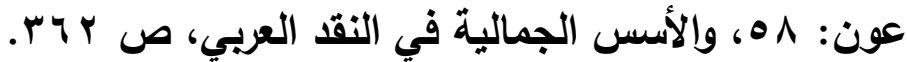
(ץ) سعيد الورقي :لغة الثعر العربي الحديث مقوماتها النفيسة

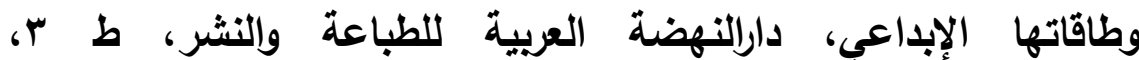

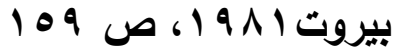

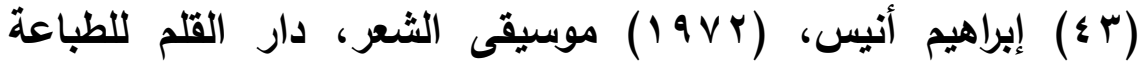
وإلنشر، بيروت، لبنان، ط؛ .ص: 10

(؛ \&) محمد بيد: القصيدة العربية الحليثة بين البنية الالالية والبنية

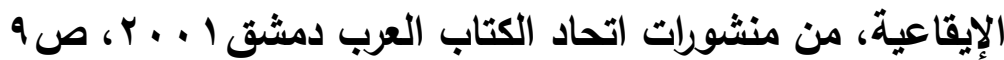
(0؛) حاتم الصكر : ما لا تؤديه الصفة المقتريات اللسانية والثعرية

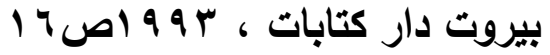
(† §) طه أحمد إبراهيم تاريخ النقا الأدبي عند العرب من العصر الجاهلي

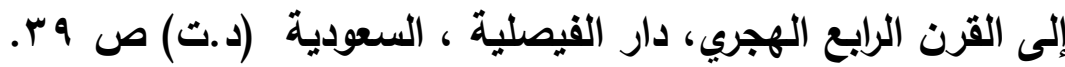
(ع) عبد الحميد الراضي: شرح تحفة الخليل في العروض والثافية،

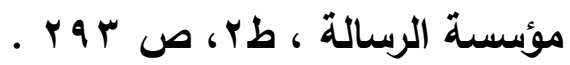
(1) ينظر: إبراهيم أنيس: موسيقى الثعر إبراهيم أنيس، موسيقى

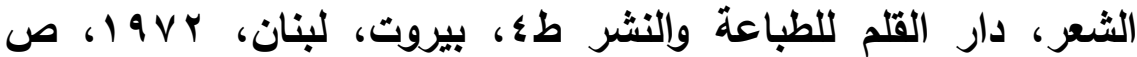




\section{دكتور/ علي عبد الظاهر علي عبد اللطيف}

(9) ) محمود حامد : الثاعر الشهيد: عبد الرحيم محمود، مؤسسة القدس للثقافة والتراث 24-2013-013

(•) فاروق المواسي: قراءة جديدة في بيان معنى الموت في قصيدة

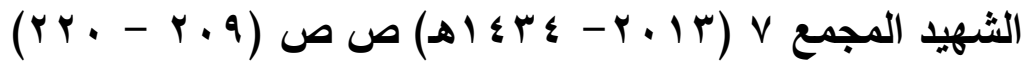
(1ه) نظر :الزمخشري: الكثاف دار إحياء التراث العربي، بيروت د.ت، ج 9 صوالr)

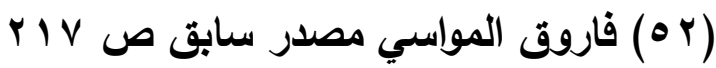
(أب) انظر مجمع اللغة العربية :المعجم الوسيط قام بإخراج الطبعة إبراهيم أنيس و عبد الحليم منتصر وعطية الصوالحي ومحمد خلف الله ، وأشرف على الطبع حسن علي عطية ومحمد شوفي أمين، الطبعة الثانية،

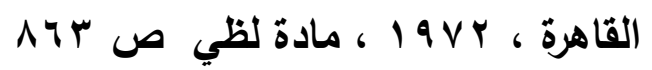

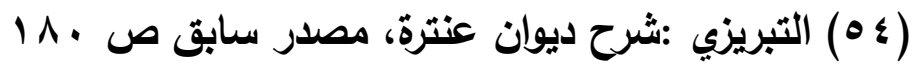

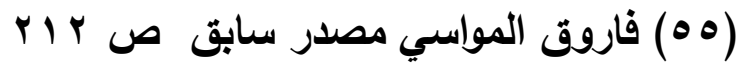




\section{قصيدة (الثهيد) لعبد الرحيم محمود قراعة أسلوبيةة}

\section{المراجع}

القرآن الكريم

• إبراهيم أنيس، موسيقى الثُر، دار القلم للطباعة والنشر ط؛،

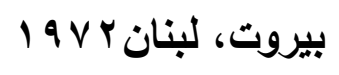

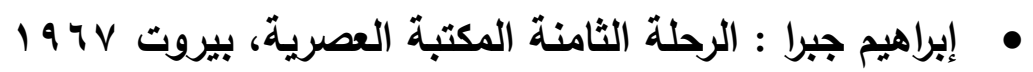

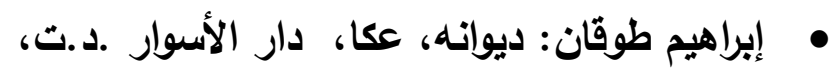

• إبراهيم عبد الستار، شعراء فلسطين في ثورتها القومية، نادي الإخاء

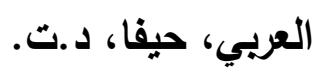

• ابن خلاون : مقدمة ابن خلاون ، تد/ حجر عاصي، منشورات دار

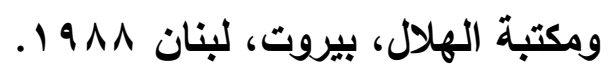
• ابن رشيق القيرواني :العمدة في محاسن الشعر وآدابه، دار الجيل b • ابن قتيبة :الثعر والثعراء ، تد/ أحمد محمد شاكر، دار المعارف، القاهرة(د.ت) • ابن منظور الأفريقي المصري: لسان العرب، دار صادر ودار بيروت،

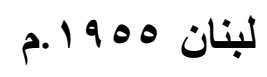

• أبو هلال العسكري : الصناعتين، تحقيق علي محمد البجاوي ومحمد

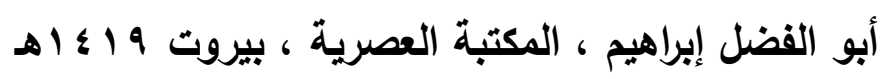
• أحمد الثايب: الأسلوب، مكتبة النهضة المصرية طه، القاهية الهرة 1979 • أحمد حسن الزيات: دفاع عن البلاغة، عالم الكتب ط ،بابيروت، I لبنان 
• أدهـم الجنـــي: أعـلام الأدب والفـن، مطبعـة مجلـة صـوت سـوريا

$$
\text { دمشق، }
$$

• أديب مصري: شرح ديوان عنترة ، عني بنشره محمود توفيق الكتبي، المطبعة الرحمانية (د.ت) • الأسـلويية والأسـلوب عبد السـلام المسديّي، الدار العربية للكتاب،

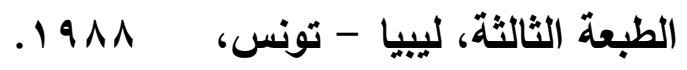
• اندريه جاك ديشين : استيعاب النصوص وتأليفها، ترجمة هيثم لمع،

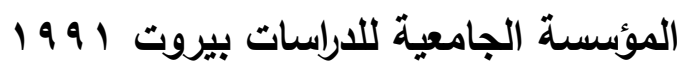
• بييرجيرو: الأسلوب والأسلوبية، ترجمة /د. منذر عياشي، مركز

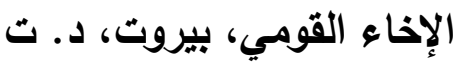

• توفيق الزيلي (ع 9 1 ) أثر اللسانيات في النقد العربي الحديث طا. الدار العربية للكتاب تونس • جبران، سليمان :نظرة جديدة على الشعر القلسطيني في عهد الانتاب /حيفا :سلسلة منشورات الكرمل، 9001 ،

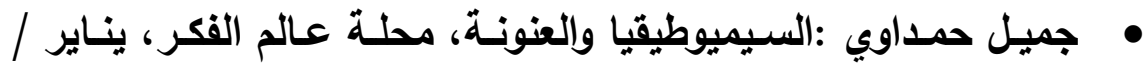

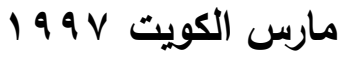
• حاتم الصكر : ما لا تؤديه الصفة المقتربات اللسانية والشعرية بيروت

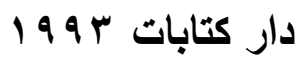
• حسني عبد الجليل: التمثيل الصوتي للمعاني دراسة نظرية في الشعر l الجاهلي، الدار الثقافية للنشر هVV • نا أبو حنا : ديوان عبد الرحيم محمود، حققه وقدم له حنا أبو حنا ، مركز إحياء التراث، الطيبة، ه19 19.

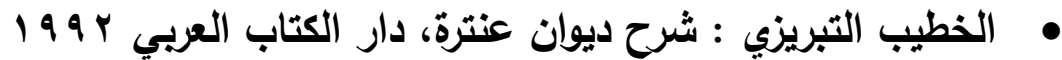




\section{قصيدة (الشهيا) لعبا الرحيم محمود قراوة أسلوبية}

• رافع يحيى : الإشراقي والأرضي في شعر البياتي، بيروت، لبنان

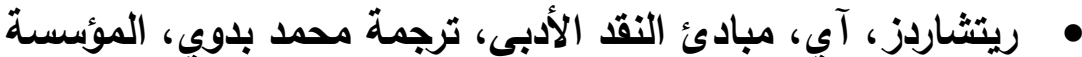
المصرية للتأليف والترجمة والنشر.

• الزمخشري: الكثاف ـ 9 بيروت :دار إحياء التراث العربي، د.ت، • سعيد الورقي لغة الثعر العربي الحديث مقوماتها النفيسة وطاقاتها

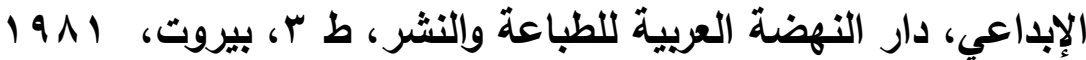

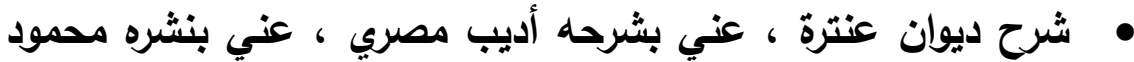
توفيق الكتبي، المطبعة الرحمانية (د.ت)

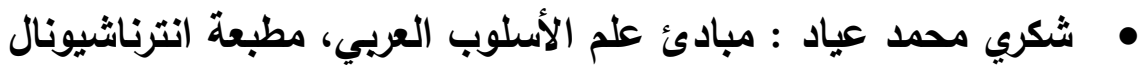
بريس، طا، 919 ام ام • • طه أحمد إبراهيم تاريخ النقد الأدبي عند العرب من العصر الجاهلي

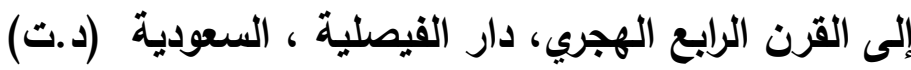

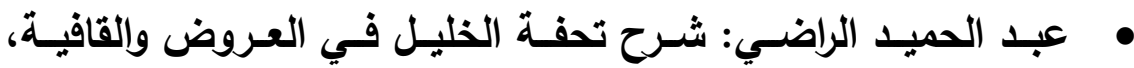

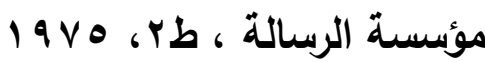
• عبد الرحمن البرقوقي : شـرح ديـوان المتتبي، دار الكتاب العريسي،

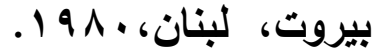
• عبد الرحيم محمود: ديوانه ، اتحاد الكتاب والصحفيين الفلسطينيين،

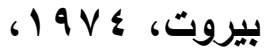
• عبد السلام المدّّي : النقد والحداثة، دار الطليعة للنشر طا، بيروت $.19 \wedge \mu$ • عبد الكريم الكرمي (أبو سلمى): "الأدب في فلسطين"، محاضرات

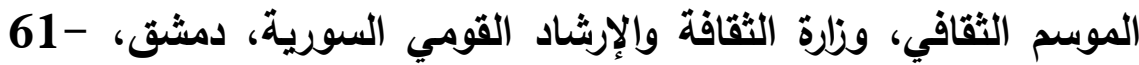




\section{دكتور/ علي عبد الظاهر علي عبد اللطيف}

• عبدالله الغذّمي: ثقافة الأسئلة مقالات في النقا والنظرية ، دار سعد الصباح، طץ،الكويت، ب9 199 • عز الـين إسـماعيل : الأسسس الجماليـة في النقــ العربـي، عرض

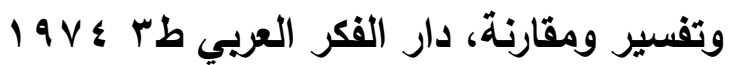
• علي بن أبي طالب : ديوانه ، تحقيق : عبد الرحمن المصطاوي،

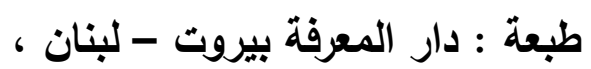
• العمدة، في محاسن الشعر وآدابـه ونقده، ابن رشيق القيروانس، ت، محمد محي الاين عبد الحميد.المكتبة التجارية الكبرى،القاهرة،ط؛ ع 9 ـ 19 • فاروق المواسي: قراعة جديدة في بيان معنى الموت في قصيدة

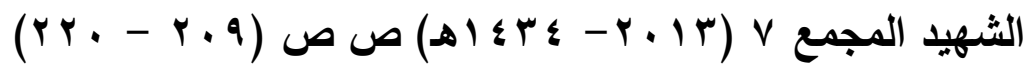
• فاروق مواسي : قراعة جديدة لقصيدة" الشهيذ "في معنى كلمة

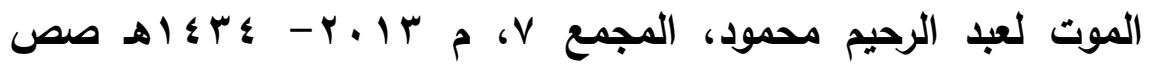
$(r+r \cdot r \cdot q)$ • فائق مصطفي و عبد الرضا علي: في النقد الأدبي الحديث، دار

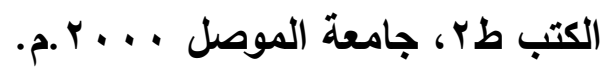
• لذة النص ، رولان بارت ، ترجمة: فؤاد صفاء ، الحسين سبحان ،

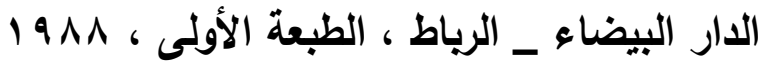
• م. لابيـه سـي فينيست: نظريـة الأنـواع الأدبيـة، ترجمـة حسن عون،

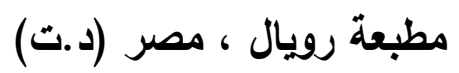
• مجمع اللغة العربية بالقاهرة : المعجم الوسيط قام بإخراج الطبعة إبراهيم أنيس و عبد الحليم منتصر وعطية الصوالحي ومحمد خلف الله ، وأشرف على الطبع حسن علي عطية ومحمد شوقي أمين، الطبعة الثانية

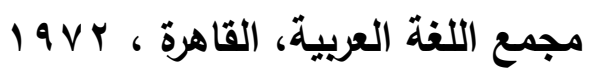




\section{قصيدة (الثهيا) لعب الرحيم محمود قراعة أسلوبية}

• محمد اللويمي : في الأسلوب والأسلوبية ،مطابع الحميضي (د.ت) . • محمد بيد القصيدة العربية الحديثة بين البنية الدلالية والبنية

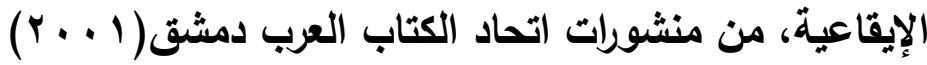

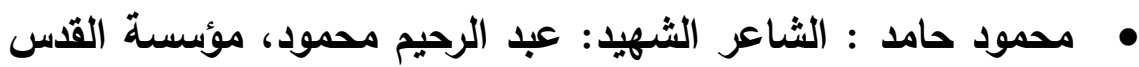
للثقافة والتراث 2013 • محمود غنايم: بين الالتزام والرفض، دراسة في شعر عبد الرحيم

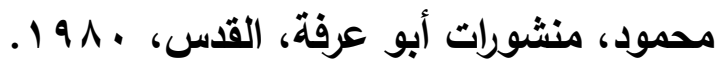
• محمود غنايم، :عبد الرحيم محمود، شاعر يبحث عن هوية، الكرمل

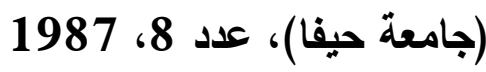
• محيي الدّ ين صبحي ديوان أبي تمَّام المجلّد الثَّتي، دار صادر بيروت لبنان 1997 ص304 • نافع عبد الله، الثاعر عبد الرحيم محمود، مكتبة دبي للتوزيع، دبي، $.19 \vee 9$

• يحيى بن حمزة العلوي :الطراز لأسرار البلاغة وعلوم حقائق الإعجاز،

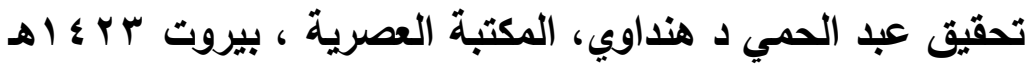
• يعقوب العودات. من أعلام الأدب والفكر في فلسطين، دار الإسراء،

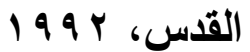
• يوسف أبو العدوس: الأسلوبية الروية والتطبيق ، دار المسيرة طا، $\Delta$ I $\leqslant Y V$ 

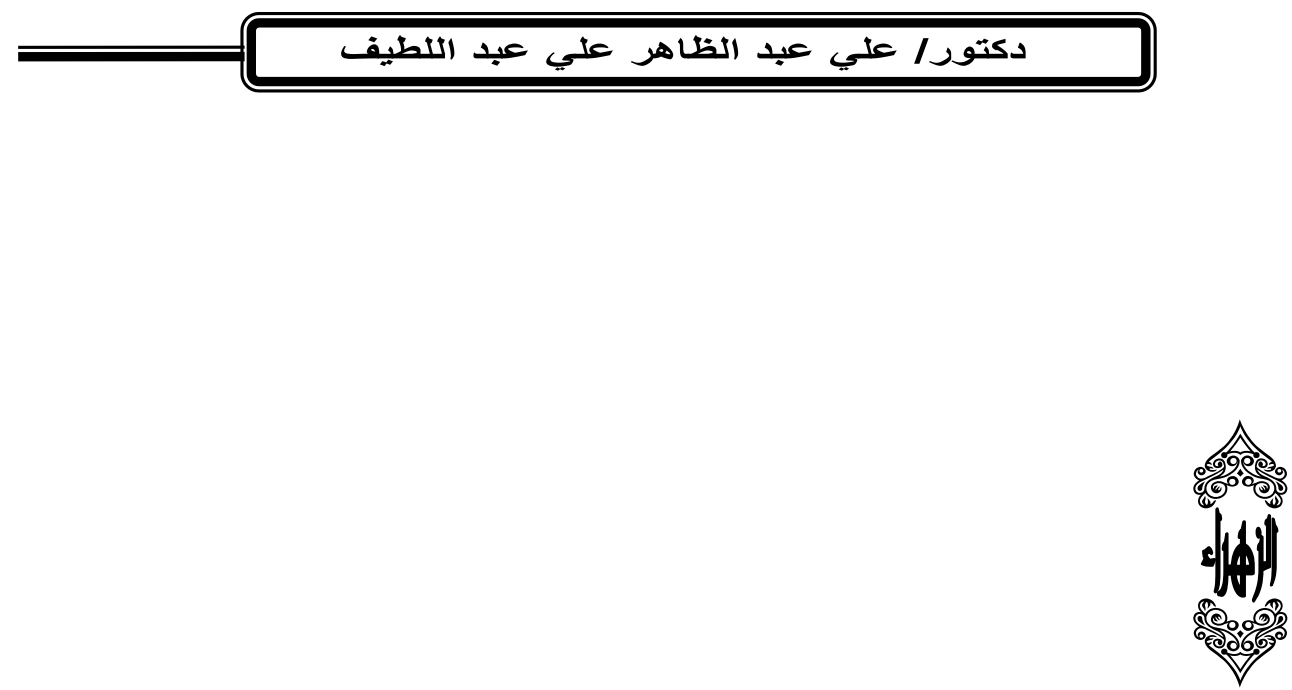